\title{
Review Article \\ Circulating Oxidative Stress Biomarkers in Clinical Studies on Type 2 Diabetes and Its Complications
}

\author{
Elisabetta Bigagli $(\mathbb{D}$ and Maura Lodovici $(\mathbb{D})$ \\ Department of Neuroscience, Psychology, Drug Research and Child Health-NEUROFARBA-Section of Pharmacology \\ and Toxicology, University of Florence, Viale Gaetano Pieraccini 6, Florence, Italy \\ Correspondence should be addressed to Elisabetta Bigagli; elisabetta.bigagli@unifi.it
}

Received 2 February 2019; Revised 1 April 2019; Accepted 23 April 2019; Published 12 May 2019

Academic Editor: Luciano Saso

Copyright (c) 2019 Elisabetta Bigagli and Maura Lodovici. This is an open access article distributed under the Creative Commons Attribution License, which permits unrestricted use, distribution, and reproduction in any medium, provided the original work is properly cited.

\begin{abstract}
Type 2 diabetes (T2DM) and its complications constitute a major worldwide public health problem, with high rates of morbidity and mortality. Biomarkers for predicting the occurrence and development of the disease may therefore offer benefits in terms of early diagnosis and intervention. This review provides an overview of human studies on circulating biomarkers of oxidative stress and antioxidant defence systems and discusses their usefulness from a clinical perspective. Most case-control studies documented an increase in biomarkers of oxidative lipid, protein, and nucleic acid damage in patients with prediabetes and in those with a diagnosis of T2DM compared to controls, and similar findings were reported in T2DM with micro- and macrovascular complications compared to those without. The inconsistence of the results regarding antioxidant defence systems renders difficulty to draw a general conclusion. The clinical relevance of biomarkers of oxidative lipid and protein damage for T2DM progression is uncertain, but prospective studies suggest that markers of oxidative nucleic acid damage such as 8hydroxy-2' -deoxyguanosine and 8-hydroxyguanosine are promising for predicting macrovascular complications of T2DM. Emerging evidence also points out the relationship between serum PON1 and serum HO1 in T2DM and its complications. Overall, enhanced oxidative damage represents an underlying mechanism of glucose toxicity in T2DM and its related microand macrovascular complications suggesting that it may be considered as a potential additional target for pharmacotherapy. Therefore, further studies are needed to understand whether targeting oxidative stress may yield clinical benefits. In this view, the measurement of oxidative stress biomarkers in clinical trials deserves to be considered as an additional tool to currently used parameters to facilitate a more individualized treatment of T2DM in terms of drug choice and patient selection.
\end{abstract}

\section{Introduction}

Type 2 diabetes (T2DM) and its complications constitute a major worldwide public health problem, with high rates of morbidity and mortality [1]. T2DM is strongly associated with both microvascular (retinopathy, nephropathy, and neuropathy) and macrovascular complications, including ischemic heart disease, peripheral vascular disease, and stroke [2]. Since T2DM often remains undiagnosed due to the mild or asymptomatic nature of this condition, vascular complications may be already present in the early phases of the disease and even in the prediabetic stage [3]. Biomarkers predictive of the occurrence and development of T2DM and its complications may therefore offer benefits in terms of early diagnosis and intervention, thus slowing down disease progression. Oxidative stress, defined as an imbalance between the production of reactive oxygen species (ROS) and antioxidant defence systems, has been often associated with the development of diabetes and its complications [4-6].

Several biomarkers of oxidative stress are available, including ROS themselves. However, since ROS are very reactive and have a short half-life, it is more suitable to estimate oxidative stress by measuring their oxidation target products, including lipid peroxidation, oxidized proteins, and oxidative nucleic acid damage [7].

In this review, we will provide an overview of human studies on circulating biomarkers of ROS-induced 
modifications of lipids, nucleic acids, and proteins as well as markers of antioxidant defence systems evaluated in the plasma, serum, or urines of T2DM patients and discuss their utility in predicting the onset and progression of the disease.

\section{Overview on the Mechanisms of Oxidative Stress Generation and Antioxidant Defence Systems}

ROS including superoxide $\left(\mathrm{O}_{2}{ }^{--}\right)$, hydroxyl radical $\left(\mathrm{OH}^{\circ}\right)$, hydrogen peroxide $\left(\mathrm{H}_{2} \mathrm{O}_{2}\right)$, and singlet oxygen $\left({ }^{1} \mathrm{O}_{2}{ }^{-}\right)$are generated during normal aerobic metabolism, and low levels are necessary for several basic biological processes including cellular proliferation and differentiation [8, 9]. Many cell types can produce ROS including macrophages, neutrophils, and endothelial and epithelial cells; however, excessive production can induce oxidative stress with detrimental effects on cellular components such as nucleic acids, proteins, and lipids [10-13] (Figure 1).

2.1. Sources of Oxidative Stress. Mitochondria have a major contribution to ROS production, particularly $\mathrm{O}_{2}{ }^{--}$, a side product of electron transport during oxidative phosphorylation. $\mathrm{H}_{2} \mathrm{O}_{2}$ is produced in vivo by many reactions, easily crosses cellular membranes and, receiving one or more electrons from iron or copper, generates $\mathrm{OH}$, the most abundant and damaging radical in the body, although very short-lived [14].

The two major ROS-generating enzymatic systems are nicotinamide adenine dinucleotide phosphate (NADPH) oxidase (NOX family) and xanthine oxidase (XO). Although the expression of NOX was initially thought to be confined to neutrophils and macrophages, it is also present in endothelial cells, cardiomyocytes, hematopoietic stem cells, and platelets [15]. During purine degradation, $\mathrm{XO}$ catalyses electron transfer to oxygen molecules which generates $\mathrm{H}_{2} \mathrm{O}_{2}$ and $\mathrm{O}_{2}{ }^{--}$species [16]. Although with minor activity, other sources of ROS include myeloperoxidase (MPO), which contributes to the progression of atherosclerotic plaque by oxidizing LDL [15], lipoxygenase (LOX), cyclooxygenase (COX), and monoamine oxidases (MAO-A and MAO-B) [17]. Endothelial nitric oxide synthase (eNOS) normally produces the potent vasodilator NO by catalysing the conversion of L-arginine to L-citrulline, and in this process, the presence of cofactor tetrahydrobiopterin $\left(\mathrm{BH}_{4}\right)$ is essential [18]. However, in the absence of either L-arginine or $\mathrm{BH}_{4}$, eNOS can produce $\mathrm{O}_{2}{ }^{--}$, in a phenomenon referred as "eNOS uncoupling" associated with increased ROS production in aging and cardiovascular diseases [18] (Figure 1).

2.2. Enzymatic and Nonenzymatic Antioxidant Defence Systems. The enzymatic and nonenzymatic antioxidant defence systems regulate ROS formation and protect biological systems from ROS-induced oxidative damage. Among the antioxidant enzymes, superoxide dismutase (SOD), catalase (CAT), glutathione peroxidase (GPx), and paraoxonase (PON) are the most studied. The nonenzymatic sources of antioxidants include ascorbic acid, tocopherol, uric acid, and glutathione (GSH); the latter acts as a ROS scavenger, and it is the substrate of the GPx enzyme; during this reaction, GSH is oxidized to GSSG, and through glutathione reductase (GR) activity, it is reconverted to GSH with NADPH as cofactor. SOD catalyses the conversion of $\mathrm{O}_{2}{ }^{-}$ to $\mathrm{H}_{2} \mathrm{O}_{2}$ that can be converted to $\mathrm{H}_{2} \mathrm{O}$ through the CAT enzyme [19] or through GSH by GPx [20]. PONs are a family of three enzymes able to hydrolyse aryl esters, lactones, and organophosphates, synthesized mainly in the liver and secreted into the plasma. PON1 is involved in lipid metabolism since it is a key functional constituent of HDL and protects low-density lipoprotein (LDL) from oxidation [21]. Among antioxidant protective systems, Nrf2 (nuclear factor-E2-related factor 2) is a transcription factor capable to induce a set of antioxidant and detoxification enzymes [22]. Under stressful conditions or in the presence of Nrf2activating compounds, Nrf2 translocates to the nucleus to induce the expression of its target genes such as heme oxygenases (HOs), a family of enzymes that catalyses the degradation of heme producing biliverdin, ferrous iron, and carbon monoxide [23]. HO1 is localized in the brain, kidney, heart, liver, and vascular smooth muscle cells, and its induction is important in initiating protective mechanisms in response to stressful stimuli [24] (Figure 1).

\section{Association between Oxidative Damage and Antioxidant Defence Systems with the Development of T2DM and Its Complications}

Chronic hyperglycaemia leads to the generation of oxidative stress in pancreatic $\beta$-cells which are particularly vulnerable to the damaging effects of excessive ROS production because of their lower abundance of antioxidant defence enzymes, compared to other tissues [25]. Due to their ability to directly damage and oxidize DNA, protein and lipid ROS lead to $\beta$ cell dysfunction and death. In addition to macromolecular damage, ROS can activate a number of cellular stresssensitive pathways that have been linked to insulin resistance and decreased insulin secretion [6]. The development of not only $\beta$-cell dysfunction and insulin resistance but also the late complications of diabetes has been linked to hyperglycaemia-induced oxidative stress through the four main molecular mechanisms: the polyol pathway, advanced glycation end product (AGE) formation, the protein kinase C- (PKC-) diacylglycerol (DAG), and the hexosamine pathways $[26,27]$. Moreover, oxidative stress originates from the oxidative biochemistry of glucose itself, which undergoes autoxidation generating ROS which in turn can directly oxidize and damage DNA, RNA, proteins, and lipids activating a number of cellular stress-sensitive pathways that cause cellular damage in the endothelial cells of large and small vessels as well as in the myocardium engaging vicious cycles that further exacerbate organ dysfunction [5]. In fact, oxidative stress is associated with increased expression of proinflammatory cytokines, growth factors, procoagulant factors, adhesion molecules, and decreased nitric oxide release, all pathophysiological events leading to endothelial dysfunction and micro- and macrovascular diseases [28, 29] (Figure 2). 
Hyperglycaemia-induced oxidative stress

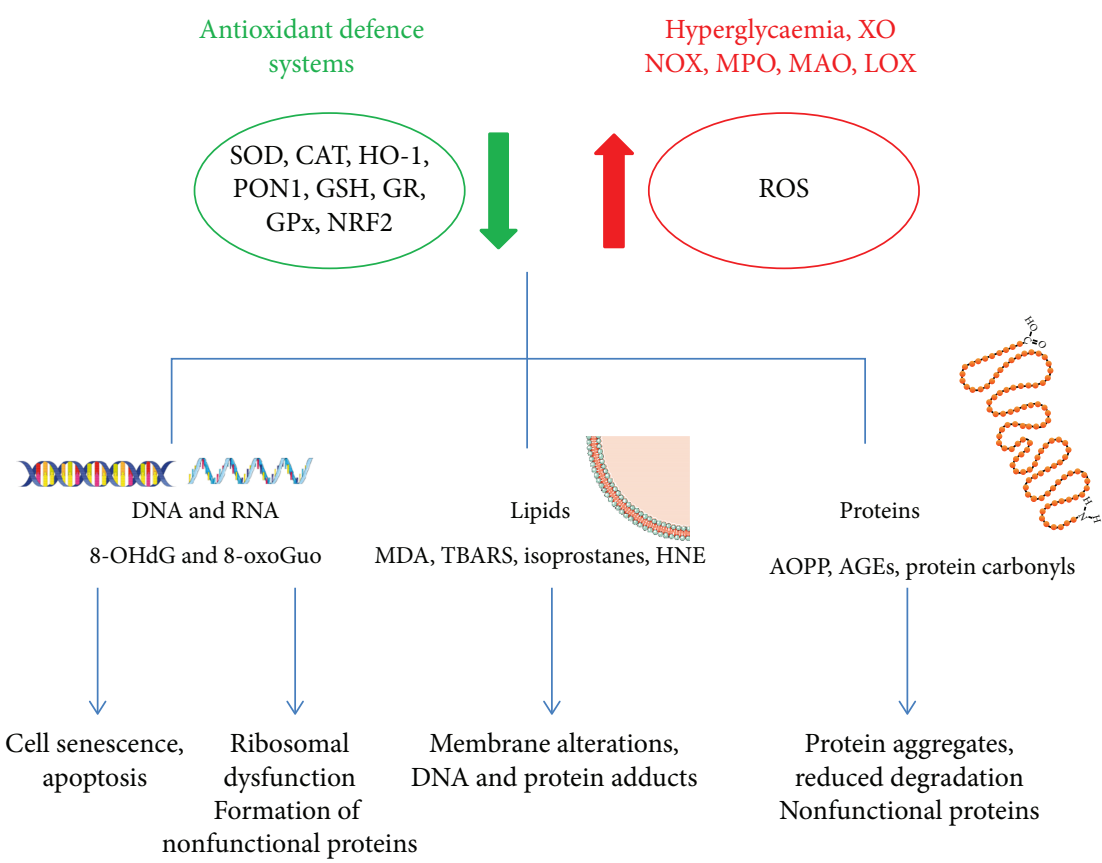

FIGURE 1: Mechanisms of hyperglycaemia-induced oxidative damage to nucleic acids, lipids and proteins. All abbreviations are spelled out in the text.

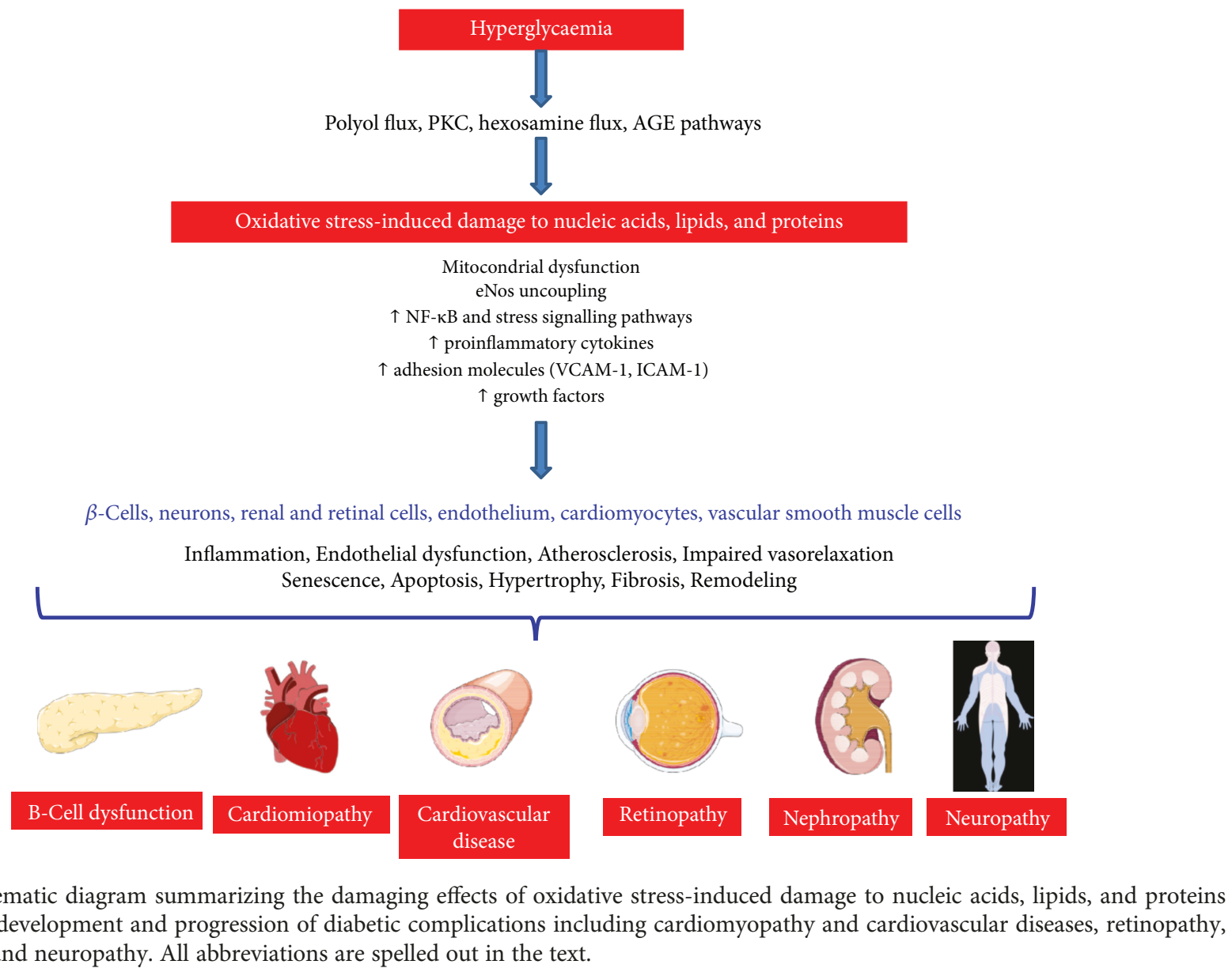

leading to the development and progression of diabetic complications including cardiomyopathy and cardiovascular diseases, retinopathy, nephropathy, and neuropathy. All abbreviations are spelled out in the text. 
3.1. AGEs in the Development of T2DM and Its Complications. In T2DM, the presence of persistently elevated glucose levels increases the frequency of AGEs, a heterogeneous group of compounds derived from the nonenzymatic glycation of proteins, lipids, and nucleic acids through the Maillard reaction [30]. Glycation, in addition to glycoxidation, can cause structural and functional impairments of plasma proteins in particular albumin [31], and it is involved in the pathophysiological mechanism of vascular diseases in T2DM [32]. By binding to their cell surface receptor (RAGE) on macrophages and endothelial cells, AGEs trigger a cascade of ROS generation and activation of proinflammatory pathways and profibrotic factors such as nuclear factor- $\kappa \mathrm{B}$ (NF- $\kappa \mathrm{B})$, vascular cell adhesion molecule-1 (VCAM-1), intercellular adhesion molecule-1 (ICAM-1), plasminogen activator inhibitor-1 (PAI-1), and monocyte chemoattractant protein-1 (MCP-1) involved in the progression of atherosclerosis and vascular pathology [33]. Immunohistochemical studies have shown that AGEs accumulate in the mesangium and glomerular capillary wall [34] and in the peripheral nerves of diabetic patients [35] suggesting their role in the pathogenesis of microvascular complications.

3.2. Lipid Peroxidation in the Development of T2DM and Its Complications. Bioactive products of lipid peroxidation induce disturbances in membrane organization, functional loss, and modifications of enzymes, carriers, and cytoskeletal and mitochondrial proteins as well as DNA bases leading to cell death or inducing alterations in the biochemical properties of these biomolecules [36].

3.3. Protein Oxidation in the Development of T2DM and Its Complications. The oxidative modification of proteins has been also linked to the pathological conditions of the vascular system: the most well-studied proteins are carbonylated proteins which accumulate as nonfunctional protein aggregates that can become cytotoxic [7].

Advanced oxidation protein products (AOPPs) are dityrosine-containing and crosslinking proteins found in atherosclerotic lesions and promote vascular inflammation, monocyte activation, and endothelial dysfunction through the overexpression of adhesion molecules such as ICAM-1 and VCAM-1 $[37,38]$.

3.4. Nucleic Acid Oxidative Damage in the Development of T2DM and Its Complications. Oxidative stress also leads to DNA damage and accumulation of 8-hydroxy- 2 '-deoxyguanosine $(8-\mathrm{OHdG})$ in atherosclerotic plaques [39] as well as in the kidney of diabetic rats [40]. Another possible mechanism by which DNA oxidation could be involved in the development of vasculopathy and atherosclerosis is the induction of cell senescence via telomeric or nontelomeric DNA damage [41]. RNA also undergoes significant oxidation forming 8-hydroxyguanosine (8-oxoGuo), which leads to ribosomal dysfunction, formation of nonfunctional or truncated proteins, and reduced levels of functional proteins [42]. RNA and DNA oxidation appears in the early stage of diabetic nephropathy [43], and the levels of oxidized purines and pyrimidines are elevated in the iris tissues of diabetic patients with glaucoma [44].

3.5. Antioxidant Defence System in the Development of T2DM and Its Complications. A defective antioxidant defence system has been also associated with diabetes and its complications: because of their low levels of antioxidants, $\beta$-cells are particularly susceptible to ROS, and hyperglycaemia itself depletes GSH by causing nonenzymatic glycation of GR and GPx, with inhibition of their reductive enzymatic activity [45]. Decreased SOD activity has been implicated in the pathogenesis of retinopathy in diabetes, and its overexpression prevented hyperglycaemia-associated production of ROS, activation of PKC, and AGE formation [46, 47]. There is also evidence that $\mathrm{HO} 1$ can protect against vascular damage and atherogenesis [48]: $\mathrm{HO} 1$ is upregulated in macrophages during the development of inflammation in atherosclerosis, with a consequently decreased expression of VCAM-1 and proinflammatory cytokines [49]; HO1 overexpression inhibits atherosclerosis by reducing ox-LDL both in the plasma and in the artery wall and reduces glomerular injury and apoptosis in diabetic rats [50-52]. PON1 also has an atheroprotective function, and its reduced activity in T2DM seems to be due to its nonenzymatic glycation [53].

\section{Biomarkers of Lipid Peroxidation}

Lipid peroxidation is the free radical oxidation of polyunsaturated fatty acids (PUFAs) such as linoleic acid or arachidonic acid, and it is capable of extensive tissue damage [54]. ROS-induced peroxidation of membrane lipids, in fact, alters the structure and the fluidity of biological membranes, which ultimately affect their function. Among the most frequently studied markers of lipid peroxidation are isoprostanes such as 8-iso-prostaglandin F2 $\alpha$ (8-iso-PGF2 $\alpha$ ), malondialdehyde (MDA), thiobarbituric acid reactive substances (TBARS), and hydroxynonenal (HNE) [55]. MDA is a highly reactive nucleophilic agent generated by both lipid peroxidation and as a byproduct of prostaglandin and thromboxane synthesis that can attack macromolecules, including amino acid or sulfhydryl moiety of proteins leading to alterations in their functions [56]. HNE is a major toxic aldehyde generated by ROS attack to $\omega-6$ polyunsaturated fatty acids and reacts with proteins forming advanced lipoxidation end products. Both HNE and MDA adducts were detected in atherosclerotic lesions [7].

Another lipid peroxidation product with prostaglandinlike structure, produced primarily from esterified arachidonic acid by nonenzymatic reactions catalysed by free radicals, is 8 -iso-PGF2 $\alpha$ [55] that can contribute to platelet activation [36].

4.1. Lipid Peroxidation in the Prediabetic Stage (Retrospective Studies). In prediabetic patients, urinary 8-iso-PGF2 $\alpha$ were higher than in healthy volunteers but negatively correlated with $\mathrm{HbA1c}$ [57]. Similarly, the levels of 8-iso-PGF2 $\alpha$ and MDA were higher in the plasma of prediabetics compared to healthy subjects but lower than in the T2DM patients 
[58]. However, other studies reported no differences in urinary isoprostanes and TBARS between prediabetes and controls $[59,60]$ (Table 1).

4.2. Lipid Peroxidation in T2DM with and without Complications (Retrospective Studies). One of the most consistent findings on lipid peroxidation markers in T2DM patients with and without complications was a significant increase in TBARS or MDA compared to healthy controls [61] (Table 1) and in T2DM patients with micro- and macrovascular complications as compared to those without [6264] (Table 2). MDA was also significantly increased in T2DM both with and without complications and performed better than ischemia-modified albumin (IMA), but it was of minor value compared to glycated haemoglobin (HbA1c) measurement in the evaluation of diabetes progression [65] (Table 2). T2DM patients with poor glycaemic control had significantly higher levels of MDA, when compared with the controlled T2DM patients and the control group [66, 67] (Tables 1 and 2). We also previously reported that circulating MDA was increased in poorly controlled T2DM with and without complications [63], and this effect was more pronounced in females [68]; however, other authors found no differences in MDA and isoprostanes between female T2DM patients with high or low HbA1c [69] (Table 2).

Significantly higher levels of MDA in T2DM with ischemic heart disease were found in the study of Djindjic et al. [70] and in T2DM with chronic kidney disease as compared to patients without complications and healthy controls [71] whereas other studies reported no differences in patients with or without nephropathy $[72,73]$ (Table 2).

\section{Advanced Glycation End Products (AGEs)}

AGEs are a complex group of compounds formed via a nonenzymatic reaction between reducing sugars and amine residues on proteins, lipids, or nucleic acids. The major AGEs in vivo appear to be formed from highly reactive intermediate carbonyl groups, including 3-deoxyglucosone, glyoxal, and methylglyoxal [74]. Some of the best chemically characterized AGEs in humans include pentosidine and N(carboxymethyl)lysine [75].

5.1. AGEs in T2DM with and without Complications (Retrospective Studies). Plasma AGE levels were significantly higher in T2DM compared to controls and in diabetics with vascular complications compared to those without $[64,76$, 77] (Table 2). On the contrary, Chou and Tseng [73] found no differences in AGE levels in T2DM with mild or severe nephropathy and those without (Table 2).

5.2. AGEs in Prospective Clinical Studies. Baseline plasma levels of AGEs were associated with several subclinical atherosclerosis parameters over 10 years of follow-up in patients with long-standing T2DM [78] and predicted the incidence of cardiovascular disease [79]. However, in a recent large prospective clinical trial, AGEs were not associated with the risk of major adverse cardiovascular disease in multivariate analysis [80] and were not associated with the risk of major lower extremity artery disease in T2DM [81] (Table 3).

\section{Biomarkers of Protein Oxidation}

Carbonyl derivatives (aldehydes and ketones) are formed by direct oxidation of amino acid residues by ROS or nonoxidative reactions with carbonyl-containing oxidized lipids [82]. Carbonyl levels are the most widely used marker of oxidative protein damage, because of the relative early formation and stability [83]. Advanced oxidation protein products (AOPPs) are formed in the reaction of chlorinated oxidants, such as chloramines and hypochlorous acid with plasma proteins, mostly albumin [82].

6.1. Protein Carbonyl and AOPPs in T2DM with and without Complications (Retrospective Studies). Protein carbonyl and AOPPs were significantly higher in T2DM patients in comparison to healthy volunteers $[62,65,76,84]$ and were also increased in those with micro- or macrovascular complications compared to T2DM without complications [62, 64, $65,76,84]$ (Tables 1 and 2). A progressive increase in AOPP plasma levels in the course of albuminuria was also noted, and AOPP was better than IMA in distinguishing patients with micro- and macroalbuminuria [85] (Table 2). Plasma AOPP concentrations were an independent risk factor for endothelial dysfunction in individuals at an early stage of diabetes [86] (Table 2). Increased protein carbonyls in red blood cells were also observed in diabetic retinopathy [87] but not in T2DM with stable ischemic heart disease [70] (Table 2). Carbonyl residues in poorly controlled T2DM with and without complications were higher compared to well controlled without complications [63] and were positively associated with the cardiovascular risk score [88] (Table 2).

6.2. Protein Carbonyl and AOPPs in Prospective Clinical Studies. A recent large prospective clinical trial indicated that both carbonyls and AOPP were not associated with the risk of major adverse cardiovascular events [80]; similarly, no association between the baseline levels of protein carbonyls and lower-extremity artery disease was observed by Nativel et al. [81] (Table 3).

\section{Biomarkers of Oxidative DNA and RNA Damage}

7.1. 8-OHdG and 8-oxoGuo in Prediabetes and in T2DM (Retrospective Studies). A well-known biomarker of oxidative DNA damage is 8-OHdG [89], and consistent evidence from observational studies showed increased urinary $8-\mathrm{OHdG}$ levels in both prediabetes and T2DM compared to controls $[57,59,90]$ (Tables 1 and 2). Urinary levels of $8-\mathrm{OHdG}$ and of the RNA oxidation marker, 8-oxo-7,8-dihydroguanosine (8-oxoGuo), were elevated in T2DM patients with and without complications compared with age-matched healthy controls [91]. Jelinek et al. [92] also identified 8-OHdG as a $\mathrm{HbA1c}$ comarker for T2DM diagnosis.

7.2. 8-OHdG and 8-oxoGuo in T2DM with and without Complications (Retrospective Studies). Patients with complications, especially macrovascular complications, exhibited higher levels of 8-OHdG than those without complications [91] (Table 2). Chou and Tseng [73] reported increased 
TABLE 1: Selected clinical retrospective studies on circulating oxidative stress markers in T2DM and prediabetes. All the studies included in this table were categorized under the class of evidence $\mathrm{C}$, retrospective studies.

\begin{tabular}{|c|c|c|c|c|c|}
\hline $\begin{array}{l}\text { Disease and } \\
\text { population }\end{array}$ & Sample & Markers & Observation & $\begin{array}{l}\text { Information on medication or } \\
\text { supplements }\end{array}$ & Reference \\
\hline $\begin{array}{l}\text { Prediabetics } \\
(N=47) \\
\text { T2DM } \\
(N=43) \\
\text { Controls } \\
(N=37)\end{array}$ & Urine & $\begin{array}{c}\text { 8-OHdG } \\
\text { 8-iso-PGF2 } \alpha\end{array}$ & $\begin{array}{c}\uparrow 8 \text {-iso-PGF } 2 \alpha \text { and } 8 \text {-OHdG in prediabetes } \\
\text { compared to controls } \\
\uparrow 8 \text {-OHdG in T2DM patients compared to } \\
\text { controls }\end{array}$ & $\begin{array}{l}\text { No medication } \\
\text { No special diet } \\
\text { No supplements }\end{array}$ & [57] \\
\hline $\begin{array}{l}\text { Prediabetics } \\
(N=176) \\
\text { Controls } \\
(N=252)\end{array}$ & $\begin{array}{l}\text { Urine } \\
\text { Erythrocytes }\end{array}$ & $\begin{array}{l}\text { 8-iso-PGF2 } \alpha \\
\text { 8-OHdG } \\
\text { GSH/GSSG }\end{array}$ & $\begin{array}{c}\text { No differences in } 8 \text {-iso-PGF2 } \alpha \\
\uparrow 8 \text {-OHdG in prediabetes group compared to } \\
\text { control } \\
\downarrow \text { GSH/GSSG in prediabetes compared to } \\
\text { control }\end{array}$ & $\begin{array}{c}\text { Antihypertensive drugs: } \\
\text { Prediabetes }(35.8 \%) \\
\text { Controls }(5.2 \%) \\
\text { Statins and anticoagulants: } \\
\text { Controls }(<4 \%) \\
\text { Prediabetes }(<16 \%)\end{array}$ & [59] \\
\hline $\begin{array}{l}\text { Prediabetics } \\
(N=49) \\
\text { T2DM } \\
(N=30) \\
\text { Controls } \\
(N=30)\end{array}$ & Plasma & $\begin{array}{l}\text { 8-iso-PGF } 2 \alpha \\
\text { MDA } \\
\text { TAOC } \\
\text { SOD }\end{array}$ & $\begin{array}{c}\uparrow 8 \text {-iso-PGF } 2 \alpha \text { and MDA in prediabetes and } \\
\text { T2DM compared to controls } \\
\uparrow 8 \text {-iso-PGF } 2 \alpha \text { in T2DM compared to } \\
\text { prediabetes } \\
\downarrow \text { TAOC in T2DM compared to controls and } \\
\text { prediabetes } \\
\downarrow \text { SOD in prediabetes compared to controls } \\
\text { No differences in TAOC between prediabetes } \\
\text { and controls } \\
\downarrow \text { SOD in T2DM compared to controls and } \\
\text { prediabetes }\end{array}$ & $\begin{array}{l}\text { No use of medication that affects } \\
\text { glucose metabolism within } 6 \\
\text { months }\end{array}$ & {$[58]$} \\
\hline $\begin{array}{l}\text { Prediabetics } \\
(N=111) \\
\text { T2DM } \\
(N=186) \\
\text { Controls } \\
(N=259)\end{array}$ & $\begin{array}{l}\text { Plasma and } \\
\text { erythrocyte }\end{array}$ & $\begin{array}{l}\text { Nrf2 } \\
\text { MDA } \\
\text { TAS } \\
\text { GPx } \\
\text { SOD } \\
\text { GSH }\end{array}$ & $\begin{array}{c}\downarrow \text { TAS and GSH in controlled and } \\
\text { uncontrolled T2DM compared to controls } \\
\text { and prediabetes } \\
\downarrow \text { Nrf2 in prediabetes and in uncontrolled } \\
\text { T2DM compared to controls } \\
\uparrow \text { MDA in uncontrolled T2DM compared to } \\
\text { controls and prediabetes and in controlled } \\
\text { T2DM compared to controls } \\
\uparrow \text { GPx in uncontrolled T2DM compared to } \\
\text { prediabetes } \\
\uparrow \text { SOD in controlled and uncontrolled T2DM } \\
\text { compared to prediabetes and controls }\end{array}$ & Not provided & {$[67]$} \\
\hline $\begin{array}{l}\text { Prediabetics } \\
(N=9) \\
\text { T2DM } \\
(N=55) \\
\text { Controls } \\
(N=29) \\
\text { Ethnicity: } \\
\text { whites, } \\
\text { blacks, } \\
\text { Brazilians }\end{array}$ & $\begin{array}{l}\text { Plasma and } \\
\text { erythrocyte }\end{array}$ & $\begin{array}{l}\text { SOD } \\
\text { CAT } \\
\text { GPx } \\
\text { TBARS }\end{array}$ & $\begin{array}{l}\text { No differences in TBARS, SOD, GPx, and } \\
\text { CAT between prediabetes and controls } \\
\uparrow \text { SOD and TBARS in T2DM compared to } \\
\text { controls and prediabetes }\end{array}$ & $\begin{array}{c}\text { Antihypertensive drugs: } 76.4 \% \text { of } \\
\text { T2DM, } 66.7 \% \text { of the pre-DM, and } \\
37.9 \% \text { of the controls } \\
\text { Among T2DM: } 92.7 \% \\
\text { sulphonylurea and/or biguanide }\end{array}$ & {$[60]$} \\
\hline $\begin{array}{l}\text { T2DM } \\
(N=215) \\
\text { Controls } \\
(N=37)\end{array}$ & Serum & $\begin{array}{l}\text { SOD } \\
\text { TBARS } \\
\text { GSH }\end{array}$ & $\begin{array}{l}\downarrow \text { SOD and GSH in T2DM compared with } \\
\text { controls } \\
\uparrow \text { TBARS in T2DM compared with controls }\end{array}$ & Not provided & {$[61]$} \\
\hline $\begin{array}{l}\text { T2DM } \\
(N=39) \\
\text { Controls } \\
(N=18)\end{array}$ & Plasma & FRAP & $\begin{array}{l}\downarrow \text { FRAP lower in T2DM with poor glycaemic } \\
\text { control than controls }\end{array}$ & $\begin{array}{l}\text { T2DM treated with metformin } \\
\text { and glibenclamide in } \\
\text { combination with other }\end{array}$ & [99] \\
\hline $\begin{array}{l}\text { T2DM } \\
(N=31)\end{array}$ & Plasma & $\begin{array}{l}\text { Protein } \\
\text { carbonyl } \\
\text { AOPP }\end{array}$ & $\begin{array}{l}\uparrow \text { protein carbonyl content and AOPPs in } \\
\mathrm{T} 2 \mathrm{DM} \text { in comparison to healthy volunteers }\end{array}$ & Not provided & [84] \\
\hline
\end{tabular}


TABLE 1: Continued.

\begin{tabular}{|c|c|c|c|c|c|}
\hline $\begin{array}{l}\text { Disease and } \\
\text { population }\end{array}$ & Sample & Markers & Observation & $\begin{array}{l}\text { Information on medication or } \\
\text { supplements }\end{array}$ & Reference \\
\hline $\begin{array}{l}\text { Controls } \\
(N=31)\end{array}$ & & $\begin{array}{l}\text { Radical } \\
\text { scavenging } \\
\text { capacity of } \\
\text { plasma }\end{array}$ & $\begin{array}{c}\downarrow \text { Radical scavenging capacity of plasma in } \\
\text { T2DM than controls }\end{array}$ & & \\
\hline $\begin{array}{l}\text { T2DM } \\
(N=80) \\
\text { Controls } \\
(N=79)\end{array}$ & Plasma & $\begin{array}{l}\text { FRAP } \\
\text { GSH } \\
\text { GR } \\
\text { GPx }\end{array}$ & $\begin{array}{c}\uparrow \text { FRAP and GR in T2DM compared to } \\
\text { controls } \\
\downarrow \text { GPx activity in T2DM compared to controls }\end{array}$ & Not provided & {$[98]$} \\
\hline $\begin{array}{l}\text { T2DM } \\
(N=115) \\
\text { Controls } \\
(N=32)\end{array}$ & Plasma & $\begin{array}{l}\text { GSH } \\
\text { GPx } \\
\text { TAS }\end{array}$ & $\begin{array}{c}\downarrow \text { GSH, GPx in T2DM compared to controls } \\
\text { No differences in TAS }\end{array}$ & $\begin{array}{l}\text { No use of vitamins, minerals, or } \\
\text { other supplements }\end{array}$ & {$[100]$} \\
\hline $\begin{array}{l}\text { T2DM } \\
(N=420) \\
\text { Controls } \\
(N=429)\end{array}$ & Plasma & $\mathrm{HO} 1$ & $\uparrow \mathrm{HO} 1$ in T2DM compared to controls & Not provided & {$[110]$} \\
\hline $\begin{array}{l}\text { T2DM } \\
(N=30) \\
\text { Controls } \\
(N=20) \\
\text { Ethnicity: } \\
\text { Indian }\end{array}$ & Serum & PON1 & $\uparrow \mathrm{PON} 1$ in controls compared to T2DM & Not provided & {$[102]$} \\
\hline $\begin{array}{l}\text { T2DM } \\
(N=90) \\
\text { Controls } \\
(N=90)\end{array}$ & Serum & PON1 & $\uparrow \mathrm{PON} 1$ in controls compared to T2DM & Not provided & {$[103]$} \\
\hline $\begin{array}{l}\text { T2DM } \\
(N=145) \\
\text { Controls } \\
(N=574)\end{array}$ & Serum & PON1 & $\uparrow \mathrm{PON} 1$ in controls compared to T2DM & $\begin{array}{c}10 \text { controls and } 15 \% \text { of T2DM } \\
\text { were on active lipid-lowering } \\
\text { treatment }\end{array}$ & {$[104]$} \\
\hline
\end{tabular}

8-iso-PGF2 $\alpha$ : 8-iso- prostaglandin F2 $\alpha$; 8-OHdG: 8-hydroxy-2' -deoxyguanosine; AGEs: advanced glycation end products; AOPP: advanced oxidation protein products; CAT: catalase; FRAP: ferric reducing ability of plasma; GSH: reduced glutathione; GSSG: oxidized glutathione; GPx: glutathione peroxidase; GR: glutathione reductase; HNE: 4- hydroxy-2-nonenal; HO1: heme oxygenase; MDA: malondialdehyde; Nrf2: nuclear factor erythroid 2; PON1: paraoxonase 1; SOD: superoxide dismutase; TBARS: thiobarbituric acid reactive substances; TAS: total antioxidant status.

plasma-8-OHdG levels in diabetic patients with micro- and macroalbuminuria compared to normoalbuminuric patients. Similarly, urinary 8-OHdG levels were significantly higher in T2DM with microvascular complications when compared to those without and better discriminate microvascular complications compared with urinary albumin [93]. On the contrary, Serdar et al. [90] found no differences in patients with and without nephropathy (Table 2).

7.3. 8-OHdG and 8-oxoGuo in Prospective Clinical Studies. Urinary excretion of 8-oxoGuo measured shortly after the diagnosis of T2DM predicted long-term mortality independent of conventional risk factors [94] (Table 3). In the ADVANCE prospective trial, increased levels of 8 -OHdG were independently associated with all-cause and cardiovascular mortality in 3766 T2DM [95]. In a recent prospective cohort study involving 1863 patients with T2DM, 8oxoGuo was associated with all-cause mortality and cardiovascular death after multiple regression analysis [96]. Moreover, recent findings suggest that urinary 8-oxoGuo provides additional information about risk to that obtained from urinary albumin and that the combined use of 8oxoGuo and urinary albumin could be useful for a better identification of patients at risk of CVD and death over a period of 19 years of follow-up [97] (Table 3).

\section{Biomarkers of Antioxidant Defence Systems}

8.1. Nonenzymatic Antioxidant Defence Systems (Retrospective Studies). Reduced levels of GSH and Nrf2 $[59,67]$ and no change in total antioxidant status [58] were reported in the prediabetic stage compared to controls. Total antioxidant status was reduced in T2DM patients compared to controls and prediabetic patients in $[58,67,84]$, increased in T2DM patients compared to controls in [98], and unchanged in [99] (Table 1). We previously reported that FRAP levels were significantly lower only in diabetics with poor glycaemic control, while patients with good glycaemic control had FRAP values similar to controls [100]; on the contrary, total antioxidant status was reduced in T2DM compared to controls, independently of glycaemic control in [67] (Table 1). 
TABLE 2: Selected clinical retrospective studies on circulating oxidative stress markers in T2DM with and without complications. All the studies included in this table were categorized under the class of evidence $\mathrm{C}$, retrospective studies.

\begin{tabular}{|c|c|c|c|c|c|}
\hline Disease and population & Sample & Markers & Observation & $\begin{array}{l}\text { Information on medication or } \\
\text { supplements }\end{array}$ & Reference \\
\hline $\begin{array}{l}\text { T2DM }(N=85) \\
\text { T2DM with micro- and } \\
\text { macrovascular } \\
\text { complications }(N=75) \\
\text { Controls }(N=60)\end{array}$ & $\begin{array}{l}\text { Plasma and } \\
\text { erythrocytes }\end{array}$ & $\begin{array}{l}\text { Protein } \\
\text { carbonyl } \\
\text { TBARS } \\
\text { FRAP } \\
\text { GSH } \\
\text { CAT }\end{array}$ & $\begin{array}{c}\uparrow \text { protein carbonyls in T2DM and } \\
\text { T2DM with complications } \\
\text { compared to controls and in T2DM } \\
\text { with complications compared to } \\
\text { T2DM without } \\
\uparrow \text { TBARS higher in T2DM and } \\
\text { T2DM with complications } \\
\text { compared to controls and in T2DM } \\
\text { with complications compared to } \\
\text { T2DM without } \\
\downarrow \text { FRAP, GSH, and CAT in T2DM } \\
\text { and T2DM with complications } \\
\text { compared to controls } \\
\downarrow \text { GSH in T2DM and T2DM with } \\
\text { complications compared to controls } \\
\text { and in T2DM with complications } \\
\text { compared to T2DM without }\end{array}$ & No antioxidants & {$[62]$} \\
\hline $\begin{array}{l}\text { T2DM with } \\
\text { complications }(N=50) \\
\text { T2DM without } \\
\text { complications }(N=50) \\
\text { Controls }(N=50)\end{array}$ & Plasma & $\begin{array}{l}\text { MDA } \\
\text { AOPP }\end{array}$ & $\begin{array}{c}\uparrow \mathrm{MDA} \text { and AOPP in T2DM } \\
\text { compared to controls } \\
\uparrow \mathrm{MDA} \text { and AOPP in T2DM with } \\
\text { complications compared to T2DM } \\
\text { without complications }\end{array}$ & $\begin{array}{c}4 \% \text { of T2DM without complications } \\
\text { and } 42 \% \text { of T2DM with } \\
\text { complications were on insulin } \\
\text { treatment } \\
96 \% \text { of T2DM without } \\
\text { complications and } 58 \% \text { of T2DM } \\
\text { with complications were on oral } \\
\text { hypoglycaemic drug treatment }\end{array}$ & {$[65]$} \\
\hline $\begin{array}{l}\text { T2DM with poor } \\
\text { glycaemic control } \\
\text { without complications } \\
(N=52) \\
\text { T2DM with poor } \\
\text { glycaemic control with } \\
\text { complications }(N=37)\end{array}$ & Plasma & $\begin{array}{l}\text { MDA } \\
\text { Protein } \\
\text { carbonyl } \\
\text { FRAP } \\
\text { SOD }\end{array}$ & $\begin{array}{c}\uparrow \text { SOD and FRAP in patients with } \\
\text { complications } \\
\uparrow \text { MDA in females with } \\
\text { complications compared to those } \\
\text { without } \\
\text { No differences in carbonyl residues } \\
\text { between males and females }\end{array}$ & $\begin{array}{l}\text { Multiregression analysis: } \\
\text { Statin treatment was associated with } \\
\text { SOD in females } \\
\text { Metformin treatment was inversely } \\
\text { associated with MDA }\end{array}$ & {$[68]$} \\
\hline $\begin{array}{l}\text { T2DM with good } \\
\text { glycaemic control } \\
\text { without complications } \\
(N=15) \\
\text { T2DM with poor } \\
\text { glycaemic control } \\
\text { without complications } \\
(N=28) \\
\text { T2DM with poor } \\
\text { glycaemic control with } \\
\text { micro- and } \\
\text { macrovascular } \\
\text { complications }(N=29)\end{array}$ & Plasma & $\begin{array}{l}\text { MDA } \\
\text { Protein } \\
\text { carbonyl } \\
\text { FRAP } \\
\text { SOD }\end{array}$ & $\begin{array}{l}\uparrow \text { MDA and carbonyl residues in } \\
\text { T2DM with poor glycaemic control } \\
\text { with and without complications } \\
\text { compared to poorly controlled } \\
\downarrow \text { FRAP in poorly controlled } \\
\text { without complications compared to } \\
\text { well controlled without } \\
\text { complications } \\
\uparrow \text { SOD in T2DM with poor } \\
\text { glycaemic control with } \\
\text { complications compared to well } \\
\text { controlled }\end{array}$ & $\begin{array}{l}\text { Medications (nonexclusive): } \\
\text { sulphonylureas }(n=12), \text { biguanides } \\
(n=46), \text { insulin }(n=30), \\
\text { thiazolidinediones }(n=2), \\
\text { meglitinides }(n=4), \text { statins }(n=31), \\
\text { and antihypertensive drugs }(n=58) \\
\text { Multiregression analysis indicated } \\
\text { no confounding effect of statin or } \\
\text { metformin }\end{array}$ & {$[63]$} \\
\hline $\begin{array}{l}\text { T2DM with } \\
\text { nephropathy }(N=50) \\
\text { T2DM without } \\
\text { nephropathy }(N=50) \\
\text { Controls }(N=50)\end{array}$ & Plasma & $\begin{array}{c}\text { MDA } \\
\text { FRAP } \\
\text { GSH }\end{array}$ & $\begin{array}{c}\uparrow \text { MDA in T2DM with nephropathy } \\
\text { compared to those without and } \\
\text { controls } \\
\downarrow \text { FRAP and GSH in T2DM with } \\
\text { and without nephropathy compared } \\
\text { to controls }\end{array}$ & $\begin{array}{l}\text { Patients on inhibitors of the renin- } \\
\text { angiotensin-aldosterone system, } \\
\text { aspirin, and vitamin D analogues } \\
\text { were advised to stop these drugs for } \\
\text { one week before inclusion in the } \\
\text { study }\end{array}$ & {$[71]$} \\
\hline $\begin{array}{l}\text { T2DM with } \\
\text { nephropathy }(N=32) \\
\text { T2DM without } \\
\text { nephropathy }(N=20) \\
\text { Controls }(N=20)\end{array}$ & Urine & 8-OHdG & $\begin{array}{l}\uparrow 8 \text {-OHdG in T2DM with and } \\
\text { without nephropathy compared to } \\
\text { controls } \\
\text { No differences between T2DM with } \\
\text { and without nephropathy }\end{array}$ & Not provided & {$[90]$} \\
\hline
\end{tabular}


TABle 2: Continued.

\begin{tabular}{|c|c|c|c|c|c|}
\hline Disease and population & Sample & Markers & Observation & $\begin{array}{l}\text { Information on medication or } \\
\text { supplements }\end{array}$ & Reference \\
\hline $\begin{array}{l}\text { T2DM patients with } \\
\text { good glycaemic control } \\
(N=27) \\
\text { T2DM patients with } \\
\text { poor glycaemic control } \\
(N=36) \\
\text { Controls }(N=16)\end{array}$ & Serum & MDA & $\begin{array}{c}\uparrow \text { MDA in T2DM with poor } \\
\text { glycaemic control vs. good } \\
\text { glycaemic control and healthy } \\
\text { volunteers }\end{array}$ & $\begin{array}{l}\text { No antioxidants supplementation in } \\
\text { the previous two months }\end{array}$ & {$[66]$} \\
\hline $\begin{array}{l}\text { T2DM female patients } \\
\text { with good glycaemic } \\
\text { control }(N=74) \\
\text { T2DM female patients } \\
\text { with poor glycaemic } \\
\text { control }(N=72)\end{array}$ & $\begin{array}{l}\text { Serum, } \\
\text { plasma, } \\
\text { PBMC }\end{array}$ & $\begin{array}{c}\text { MDA } \\
\text { F2- } \\
\text { isoprostanes } \\
\text { FRAP } \\
\text { GSH/GSSG } \\
\text { SOD } \\
\text { CAT } \\
\text { GPx }\end{array}$ & No differences & $\begin{array}{l}\text { Similar distribution of metformin, } \\
\text { insulin, and other antidiabetic } \\
\text { medications in the two groups }\end{array}$ & {$[69]$} \\
\hline $\begin{array}{l}\text { T2DM without } \\
\text { nephropathy }(N=22) \\
\text { T2DM with mild } \\
\text { nephropathy }(N=22) \\
\text { T2DM with severe } \\
\text { nephropathy }(N=15)\end{array}$ & $\begin{array}{l}\text { Plasma and } \\
\text { RBC }\end{array}$ & $\begin{array}{l}\text { AGEs } \\
\text { MDA } \\
\text { 8-OHdG } \\
\text { Vitamin C } \\
\text { TAS } \\
\text { GSH } \\
\text { GPx } \\
\text { CAT } \\
\text { SOD }\end{array}$ & $\begin{array}{c}\uparrow 8 \text {-OHdG in T2DM with micro- } \\
\text { and macroalbuminuria compared } \\
\text { to normoalbuminuric patients } \\
\downarrow \text { vitamin C in T2DM } \\
\text { with micro- and macroalbuminuria } \\
\text { compared to normoalbuminuric } \\
\text { patients } \\
\text { No differences in AGE, MDA, TAS, } \\
\text { GSH, GPx, CAT, and SOD }\end{array}$ & $\begin{array}{l}\text { Distributions were comparable in } \\
\text { the three groups for aspirin and } \\
\text { drugs for diabetes control (four } \\
\text { kinds of medications) } \\
\text { A lower percentage of T2DM } \\
\text { without nephropathy used insulin } \\
\text { and antihyperlipidemic drugs than } \\
\text { T2DM with severe nephropathy } \\
\text { A higher percentage of T2DM with } \\
\text { mild nephropathy used metformin } \\
\text { than the other two groups }\end{array}$ & {$[73]$} \\
\hline $\begin{array}{l}\text { T2DM with } \\
\text { complications } \\
(N=267) \\
\text { T2DM without } \\
\text { complications } \\
(N=366) \\
\text { Controls }(N=683)\end{array}$ & Urine & $\begin{array}{l}\text { 8-OHdG } \\
\text { 8-oxoGuo }\end{array}$ & $\begin{array}{c}\uparrow \text { 8-OHdG and } \\
\text { 8-oxoGuo in T2DM compared to } \\
\text { controls } \\
\uparrow \text { 8-oxoGuo in T2DM with } \\
\text { macrovascular complications } \\
\text { compared to those without } \\
\text { complications }\end{array}$ & Not provided & [91] \\
\hline $\begin{array}{l}\text { T2DM with } \\
\text { microvascular } \\
\text { complications }(N=30) \\
\text { T2DM without } \\
\text { complications }(N=24) \\
\text { Controls }(N=22)\end{array}$ & Urine & 8-OHdG & $\begin{array}{l}\uparrow 8 \text {-OHdG in T2DM with } \\
\text { microvascular complications than } \\
\text { those without complications }\end{array}$ & Not provided & [93] \\
\hline $\begin{array}{l}\text { T2DM with } \\
\text { microvascular } \\
\text { complications }(N=25) \\
\text { T2DM with } \\
\text { macrovascular } \\
\text { complications }(N=25) \\
\text { T2DM without } \\
\text { complications }(N=25)\end{array}$ & Serum & $\begin{array}{l}\text { AGEs } \\
\text { Protein } \\
\text { carbonyl } \\
\text { MDA } \\
\text { AOPP }\end{array}$ & $\begin{array}{l}\uparrow \text { MDA, protein carbonyl, AOPP, } \\
\text { and AGE in T2DM with micro- and } \\
\text { macrovascular complications } \\
\text { compared to T2DM without } \\
\text { complications }\end{array}$ & Not provided & {$[64]$} \\
\hline $\begin{array}{l}\text { T2DM with micro-and } \\
\text { macrovascular } \\
\text { complications }(N=55) \\
\text { T2DM without } \\
\text { complications }(N=26) \\
\text { Controls }(N=20)\end{array}$ & Plasma & $\begin{array}{l}\text { AGEs } \\
\text { AOPPs }\end{array}$ & $\begin{array}{c}\uparrow \text { AGE and AOPPs in T2DM } \\
\text { compared to controls } \\
\uparrow \text { AGE in T2DM with complications } \\
\text { compared to those without }\end{array}$ & $\begin{array}{l}\text { No antioxidant supplements } \\
\text { Lipid- or triglyceride-lowering } \\
\text { drugs: } 62 \% \text { of T2DM without } \\
\text { complications and } 73 \% \text { with } \\
\text { complications }\end{array}$ & {$[76]$} \\
\hline $\begin{array}{l}\text { T2DM }(N=153) \\
\text { Controls }(N=65)\end{array}$ & Plasma & AOPP & $\begin{array}{c}\uparrow \text { AOPP in T2DM with albuminuria } \\
\text { compared to those without } \\
\text { AOPP was better than IMA in }\end{array}$ & Not provided & {$[85]$} \\
\hline
\end{tabular}


TABle 2: Continued.

\begin{tabular}{|c|c|c|c|c|c|}
\hline Disease and population & Sample & Markers & Observation & $\begin{array}{l}\text { Information on medication or } \\
\text { supplements }\end{array}$ & Reference \\
\hline & & & $\begin{array}{l}\text { distinguishing patients with micro- } \\
\text { and macroalbuminuria }\end{array}$ & & \\
\hline $\begin{array}{l}\text { Newly diagnosed } \\
\text { T2DM without } \\
\text { albuminuria }(N=112) \\
\text { Newly diagnosed } \\
\text { T2DM with } \\
\text { albuminuria }(N=35) \\
\text { Controls }(N=49)\end{array}$ & Plasma & AOPP & $\begin{array}{c}\uparrow \mathrm{AOPP} \text { in T2DM with albuminuria } \\
\text { compared to those without and to } \\
\text { controls }\end{array}$ & $\begin{array}{c}\text { No hypoglycaemic or } \\
\text { antihypertensive drugs, lipid- } \\
\text { lowering agents, or antioxidants } \\
\text { (vitamin } \mathrm{C} \text {, vitamin E, or lipoic acid) }\end{array}$ & {$[86]$} \\
\hline $\begin{array}{l}\text { Poorly controlled } \\
\text { T2DM with vascular } \\
\text { complication }(N=44) \\
\text { Poorly controlled } \\
\text { T2DM without vascular } \\
\text { complication }(N=44) \\
\text { Controls }(N=31)\end{array}$ & Plasma & AGE & $\begin{array}{l}\uparrow \mathrm{AGE} \text { in T2DM with complications } \\
\text { compared to those without }\end{array}$ & Not provided & {$[77]$} \\
\hline $\begin{array}{l}\text { T2DM with } \\
\text { nephropathy }(N=30) \\
\text { T2DM without } \\
\text { nephropathy }(N=34) \\
\text { Controls }(N=20)\end{array}$ & $\begin{array}{l}\text { Serum and } \\
\text { erythrocytes }\end{array}$ & $\begin{array}{l}\text { MDA } \\
\text { SOD }\end{array}$ & $\begin{array}{c}\uparrow \text { MDA in T2DM compared to } \\
\text { controls } \\
\text { No changes in MDA and SOD in } \\
\text { T2DM with and without } \\
\text { nephropathy }\end{array}$ & $\begin{array}{l}\text { Distributions were comparable in } \\
\text { the groups with and without } \\
\text { nephropathy for antihypertensives, } \\
\text { statins, metformin, sulfonylureas, } \\
\text { and insulin }\end{array}$ & {$[72]$} \\
\hline $\begin{array}{l}\text { T2DM with stable } \\
\text { ischemic heart disease } \\
(N=30) \\
\text { T2DM without stable } \\
\text { ischemic heart disease } \\
(N=30)\end{array}$ & $\begin{array}{l}\text { Plasma and } \\
\text { serum }\end{array}$ & $\begin{array}{l}\text { Protein } \\
\text { carbonyl } \\
\text { MDA }\end{array}$ & $\begin{array}{c}\uparrow \text { MDA in T2DM with stable } \\
\text { ischemic heart disease } \\
\text { No differences in protein carbonyl }\end{array}$ & $\begin{array}{c}\text { No antioxidants } \\
\text { Distributions were comparable in } \\
\text { the groups with and without } \\
\text { ischemic heart disease for Ca } \\
\text { channel blockers, beta blockers, } \\
\text { ACE inhibitors/ARB, statins, and } \\
\text { acetylsalicylic acid }\end{array}$ & {$[70]$} \\
\hline $\begin{array}{l}\text { T2DM with } \\
\text { retinopathy }(N=45) \\
\text { T2DM without } \\
\text { retinopathy }(N=19) \\
\text { Controls }(N=20)\end{array}$ & $\begin{array}{l}\text { Red blood } \\
\text { cells }\end{array}$ & $\begin{array}{l}\text { Protein } \\
\text { carbonyl }\end{array}$ & $\begin{array}{l}\uparrow \text { protein carbonyl in T2DM with } \\
\text { retinopathy compared to those } \\
\text { without and to controls }\end{array}$ & No vitamin $\mathrm{E}$ or $\mathrm{C}$ supplementation & {$[87]$} \\
\hline $\begin{array}{l}\text { T2DM with } \\
\text { normoalbuminuria } \\
(N=28) \\
\text { T2DM with } \\
\text { microalbuminuria } \\
(N=28) \\
\text { T2DM with } \\
\text { macroalbuminuria } \\
(N=28) \\
\text { Controls }(N=28)\end{array}$ & Urine & $\mathrm{HO} 1$ & $\begin{array}{c}\uparrow \mathrm{HO} 1 / \text { creatinine in T2DM with } \\
\text { microalbuminuria and } \\
\text { macroalbuminuria compared to } \\
\text { those with normoalbuminuria and } \\
\text { control } \\
\uparrow \mathrm{HO} 1 / \text { creatinine in T2DM with } \\
\text { normoalbuminuria than controls }\end{array}$ & Not provided & [111] \\
\hline $\begin{array}{l}\text { T2DM with } \\
\text { retinopathy }(N=25) \\
\text { T2DM without } \\
\text { retinopathy }(N=29) \\
\text { Healthy control } \\
(N=24)\end{array}$ & Serum & PON1 & $\begin{array}{l}\uparrow \text { PON1 in controls compared to } \\
\text { T2DM } \\
\uparrow \text { PON1 in T2DM without } \\
\text { retinopathy compared to T2DM } \\
\text { with retinopathy }\end{array}$ & $\begin{array}{l}\text { No patient under lipid-lowering } \\
\text { therapy } \\
\text { No patient was taking vitamin or } \\
\text { mineral supplements or food } \\
\text { fortified with vitamins }\end{array}$ & {$[105]$} \\
\hline $\begin{array}{l}\text { T2DM with } \\
\text { macrovascular } \\
\text { complications } \\
(N=130) \\
\text { T2DM without } \\
\text { complications } \\
(N=135)\end{array}$ & Serum & $\begin{array}{l}\text { PON1 } \\
\text { AGEs }\end{array}$ & $\begin{array}{c}\uparrow \text { PON1 in controls compared to } \\
\text { T2DM } \\
\uparrow \text { PON1 in T2DM without } \\
\text { complications compared to T2DM } \\
\text { with macrovascular complications } \\
\uparrow \text { AGE in T2DM compared to } \\
\text { controls }\end{array}$ & $\begin{array}{l}\text { No antioxidants } \\
\text { Distribution of antihypertensive } \\
\text { and lipid-lowering drugs not } \\
\text { provided }\end{array}$ & [106] \\
\hline
\end{tabular}


TABLe 2: Continued.

\begin{tabular}{|c|c|c|c|c|}
\hline Disease and population & Sample & Markers & $\begin{array}{l}\text { Information on medication or } \\
\text { supplements }\end{array}$ & Reference \\
\hline $\begin{array}{l}\text { Controls }(N=171) \\
\text { Ethnicity: Indians }\end{array}$ & & & $\begin{array}{l}\uparrow \mathrm{AGE} \text { in T2DM with complications } \\
\text { compared to those without }\end{array}$ & \\
\hline
\end{tabular}

Reduced GSH [67] was observed in T2DM with good and poor glycaemic control compared to controls [61, 67, 99], whereas Nrf2 was reduced only in T2DM with poor glycaemic control [67] (Table 1). Grindel et al. [69] found no differences in GSH and FRAP between T2DM female patients with and without good glycaemic control. Comparing T2DM patient with complication to those without, decreased GSH and FRAP $[62,71]$ and vitamin $C$ [73] increase in FRAP levels [68], and no differences in GSH and total antioxidant status were reported [73] (Table 2). Recently, in a large prospective clinical trial, the total antioxidant capacity of plasma was not associated with the risk of major cardiovascular events [80] (Table 3).

\subsection{Enzymatic Antioxidant Defence Systems (Retrospective} and Prospective Studies). Regarding antioxidant enzymatic defence systems, SOD activity was reduced [58] or unchanged $[67,70]$ in prediabetes compared to controls and either increased $[60,67]$ or decreased $[58,61]$ in T2DM compared to controls. No differences in CAT and GPx activity were observed between prediabetes and control in [60] (Table 1). GPx was increased in uncontrolled T2DM compared to prediabetes [67] and decreased compared to controls [98, 99] (Table 1).

Inconsistent results on SOD, CAT, and GPx were also found when T2DM patients with complications were compared to those without complications $[62,63,68,69,72$, 73] (Table 2). Regarding the protective antioxidant defence of GPx, González de Vega et al. [101] found the presence of glycated GPx in sera from diabetic patients, with lower GPx activity than that measured in healthy individuals, and this reduction was greater in patients with higher $\mathrm{HbAlc}$.

PON1 levels decreased in T2DM patients compared to controls and correlated to the duration of diabetes [102106] (Table 1). PON1 was reduced in T2DM with retinopathy and macrovascular disease compared to those without $[105,106]$ and predicted cardiovascular events in T2DM [107] (Table 3). Lower PON1 activity was associated with an increased risk of developing T2DM in a longitudinal study with a 20-year follow-up [108]; on the contrary, in the PREVEND prospective study involving 5947 participants, no association was found [109] (Table 3). Plasma HO1 concentrations were significantly increased in new-T2DM patients compared to controls and correlated with plasma glucose levels [110] (Table 1); increased urine HO1 levels were detected in T2DM before the onset of significant albuminuria and were associated with renal derangement in patients with established diabetic nephropathy [111] (Table 2).

\section{Discussion}

Several oxidative stress biomarkers in the form of lipid, protein, and nucleic acid oxidation products have been studied in T2DM patients, while fewer data in the prediabetic stage are currently available. In the majority of the studies, urinary and plasma levels of 8 -iso-PGF $2 \alpha$ and urinary levels of 8 OHdG were elevated in the prediabetic stage representing potential early disease markers in patients at risk for T2DM which may also enable therapeutic interventions from the early stages of diabetes where cardiovascular risk is already increased. Similarly, when oxidative stress biomarkers were evaluated in patients with clinical diagnosis of T2DM, the most consistent finding across many of these studies was a significant increase in the plasma levels of TBARS, MDA, AGEs, protein carbonyls, and AOPP and in the urinary levels of 8-OHdG in T2DM patients compared to healthy controls; similar results were observed in T2DM patients with micro-and macrovascular complications in comparison to those without complications.

These studies present some limitations that should be addressed in future research: in particular, neither potential gender-related differences nor racial disparities in oxidative stress biomarkers have been actively investigated so far; nevertheless, both racial and gender differences in the markers of oxidative stress have been reported $[68,112,113]$. A limitation of many studies is that medications such as statins, $\beta$-blockers, angiotensin-converting enzyme inhibitors, and angiotensin receptor blockers which exhibit antioxidant effects were not always analysed as potential confounding factors [114]; a limitation of many studies is that these medications were not always included in the analyses as potential confounding factors.

From an overall point of view, despite the heterogeneity of T2DM patients in terms of stage and duration and the presence of different complications, what emerges from retrospective human studies is that there is an association between increased circulating oxidative damage biomarkers, T2DM, and its complications. Nevertheless, none of these biomarkers has never reached clinical practice mainly because of the lack of standardized methods and reference range intervals and the lack of validation in prospective trials. In fact, in spite of the promising results from observational clinical studies, a recent large prospective study concluded that none of the different biomarkers of oxidative stress used (AGE, AOPP, protein carbonyls, and antioxidant capacity of plasma) was associated with adverse cardiovascular events [80]. However, encouraging results were obtained with the nucleic acid oxidation biomarkers, 8-oxoGuo and 8-OHdG measured in the urines, 
TABLE 3: Selected clinical prospective studies on circulating oxidative stress markers in T2DM. Categories are based on the following evidence levels: (A) large prospective studies and (B) prospective studies.

\begin{tabular}{|c|c|c|c|c|c|c|}
\hline $\begin{array}{l}\text { Disease and } \\
\text { population }\end{array}$ & Sample & Markers & Observation & $\begin{array}{l}\text { Class of } \\
\text { evidence }\end{array}$ & $\begin{array}{l}\text { Information on medication or } \\
\text { supplements }\end{array}$ & Reference \\
\hline $\begin{array}{l}\text { T2DM } \\
(N=1468)\end{array}$ & Plasma & $\begin{array}{l}\text { AOPP } \\
\text { AGE } \\
\text { Protein } \\
\text { carbonyl } \\
\text { Total } \\
\text { reductive } \\
\text { capacity of } \\
\text { plasma }\end{array}$ & $\begin{array}{c}\text { AOPP and total } \\
\text { reductive capacity of plasma were not } \\
\text { associated with the risk of major adverse } \\
\text { cardiovascular events } \\
\uparrow \text { AGE and carbonyls were associated with } \\
\text { the risk of major adverse cardiovascular } \\
\text { events in univariate analysis but not in } \\
\text { multivariate analysis }\end{array}$ & $\mathrm{A}$ & $\begin{array}{l}\text { Use of statins included in the } \\
\text { multivariate model }\end{array}$ & {$[80]$} \\
\hline $\begin{array}{l}\text { T2DM } \\
(N=3766)\end{array}$ & Urine & 8-OHdG & $\begin{array}{c}\uparrow 8 \text {-OHdG is independently associated with } \\
\text { all-cause mortality and cardiovascular } \\
\text { mortality }\end{array}$ & A & $\begin{array}{l}\text { Use of aspirin, statins, beta } \\
\text { blockers, and ACE inhibitors/ARB } \\
\text { included in statistical analysis }\end{array}$ & {$[95]$} \\
\hline $\begin{array}{l}\text { T2DM } \\
(N=411)\end{array}$ & Plasma & AGEs & $\begin{array}{l}\text { Baseline AGEs associated with subclinical } \\
\text { atherosclerosis parameters over } 10 \text { years of } \\
\text { follow-up }\end{array}$ & B & No clear indication & {$[78]$} \\
\hline $\begin{array}{l}\text { T2DM } \\
(N=1900)\end{array}$ & Urine & $\begin{array}{l}\text { 8-oxoGuo } \\
\text { 8-OHdG }\end{array}$ & $\begin{array}{c}\text { 8-oxoGuo was associated with all-cause } \\
\text { mortality and cardiovascular death } \\
\text { 8-OHdG was not } \\
\text { associated with survival }\end{array}$ & $\mathrm{A}$ & $\begin{array}{l}\text { No clear indication whether drugs } \\
\text { were included in statistical analysis }\end{array}$ & {$[96]$} \\
\hline $\begin{array}{l}\text { T2DM } \\
(N=1381)\end{array}$ & Urine & 8-oxoGuo & $\begin{array}{l}\text { 8-oxoGuo was associated with all-cause } \\
\text { mortality and CVD at diagnosis and } \\
\text { at } 6 \text {-year follow-up }\end{array}$ & A & No clear indication & {$[97]$} \\
\hline $\begin{array}{l}\text { Newly } \\
\text { diagnosed } \\
\text { T2DM } \\
(N=1381)\end{array}$ & Urine & $\begin{array}{l}\text { 8-oxoGuo } \\
\text { 8-OHdG }\end{array}$ & $\begin{array}{l}\text { 8-oxoGuo at diagnosis predicted all-cause } \\
\text { and diabetes-related mortality over } 6 \text { years } \\
\text { 8-OHdG was not associated with survival }\end{array}$ & A & No clear indication & {$[94]$} \\
\hline $\begin{array}{l}\text { T2DM } \\
(N=716)\end{array}$ & Plasma & AGEs & $\begin{array}{c}\text { AGEs were associated with incident } \\
\text { cardiovascular events over 3-7 years of } \\
\text { follow-up }\end{array}$ & B & No clear indication & {$[79]$} \\
\hline $\begin{array}{l}\text { T2DM } \\
(N=1412)\end{array}$ & Plasma & $\begin{array}{l}\text { AGEs } \\
\text { Protein } \\
\text { carbonyls }\end{array}$ & $\begin{array}{l}\text { No independent associations between } \\
\text { lower-extremity artery disease and AGE or } \\
\text { protein carbonyls }\end{array}$ & A & $\begin{array}{l}\text { Use of insulin therapy and } \\
\text { antihypertensive,statin, fibrate, and } \\
\text { antiplatelet drugs included in } \\
\text { statistical analysis }\end{array}$ & {$[81]$} \\
\hline $\begin{array}{l}\text { T2DM } \\
(N=108)\end{array}$ & Serum & PON1 & $\begin{array}{l}\text { Lower PON1 activity and concentration } \\
\text { were associated with an increased risk of } \\
\text { developing cardiovascular disease }\end{array}$ & B & Not provided & [107] \\
\hline $\begin{array}{l}(N=234) \\
\text { with no } \\
\text { preexisting } \\
\text { diabetes }\end{array}$ & Serum & PON1 & $\begin{array}{c}\text { Lower PON1 activity and concentration } \\
\text { were associated with an increased risk of } \\
\text { developing T2DM }\end{array}$ & B & Not provided & {$[108]$} \\
\hline $\begin{array}{l}(N=5947) \\
\text { with no } \\
\text { preexisting } \\
\text { diabetes }\end{array}$ & Serum & PON1 & $\begin{array}{l}\text { Incident T2DM was not associated with } \\
\text { PON1 }\end{array}$ & A & Not provided & [109] \\
\hline
\end{tabular}

8-OHdG: 8-hydroxy-2' -deoxyguanosine; 8-oxoGuo: 8-oxo-7,8-dihydroguanosine; AGEs: advanced glycation end products; AOPP: advanced oxidation protein products; IMA: ischemia-modified albumin; PON1: paraoxonase 1.

which maybe useful to predict micro- and macrovascular complications of T2DM. Data referring to antioxidant defence systems are more inconclusive since they have been found either decreased or increased. Emerging evidence also points out the relationship between serum PON1 and HO1 in T2DM and its complications, and a recent meta-analysis demonstrated that PON1 was significantly associated with the susceptibility of T2DM and to the development of macro- and microangiopathy [115].
From a mechanistic point of view, even if oxidative stress is involved in nearly all stages of micro- and macrovascular disease development [116-118], the relative importance of each biomarker of oxidative nucleic, protein, or lipid damage and whether one may be related to a greater extent with the key mechanisms of T2DM and its complications need further investigations (Figure 2).

The evaluation of oxidative damage biomarkers may be also relevant for better phenotyping patients; Seddon et al. 
[116] highlighted that oxidative stress is a redox disease and a potential covariate in predicting patient recovery on an antidiabetic treatment; this highlights the need to identify those patients who are likely to need specific pharmacological strategies that can target oxidative stress, beyond lowering glucose.

Moreover, several drugs used for the treatment of T2DM have been shown to exert pleiotropic effects [117] but, to date, the relationship between glycaemic control, oxidative stress, and endogenous antioxidant defence systems has received limited attention in clinical studies.

In particular, it is the case of the newer glucose-lowering drugs such as GLP-1 analogues, dipeptidyl peptidase 4 (DPP4) inhibitors, and sodium-glucose cotransporter 2 inhibitors (SGLT2i). Interestingly, a recent large study demonstrated that GLP-1 analogues, beyond improving glycaemic control and promoting weight loss, improve cardiovascular outcomes in patients at high cardiovascular risk [118], and this effect was associated with reduced oxidative stress [119].

\section{Conclusions}

There is a need to improve our knowledge about T2DM and its complications in order to be able to develop new targets of intervention. Oxidative stress represents one of the mechanisms involved in the pathogenesis and progression of T2DM and its complications, suggesting that it may be considered as an additional target for pharmacotherapy. In this view, the measurement of the circulating biomarkers of oxidative stress offers several advantages including easy collection, low cost, and the possibility of use in large clinical studies. At present, among several biomarkers, urinary 8-OHdG and 8-oxoGuo, serum PON1 and $\mathrm{HO} 1$ seem to be the most promising for predicting cardiovascular disease in T2DM.

However, the measurement of oxidative stress biomarkers may have several other clinical applications such as patient selection and stratification as well as monitoring the clinical efficacy of medications supposed to affect oxidative stress. Direction for future research should also include further mechanistic studies linking each biomarker to disease onset and progression including their temporal variations from the early to the late stages of the disease.

By better targeting the mechanisms involved in disease pathogenesis and progression, with old or new therapeutic strategies, we can expect to improve the outcomes of T2DM patients. Therefore, the measurement of oxidative stress biomarkers in clinical trials deserves to be considered as an additional tool to currently used parameters to facilitate a more individualized treatment of T2DM in terms of drug choice and patient selection.

\section{Conflicts of Interest}

The authors declare that there is no conflict of interest regarding the publication of this paper.

\section{Acknowledgments}

This research was supported by a grant from Ente Cassa di Risparmio di Firenze No. 2017.0841.

\section{References}

[1] K. M. V. Narayan, "Type 2 diabetes: why we are winning the battle but losing the war?," Diabetes Care, vol. 39, no. 5, pp. 653-663, 2015.

[2] F. Giacco and M. Brownlee, "Oxidative stress and diabetic complications," Circulation Research, vol. 107, no. 9, pp. 1058-1070, 2010.

[3] IDF Diabetes Atlas, 7th Edition edition7th Edition edition, , 2017.

[4] J. Ahmad, "Management of diabetic nephropathy: recent progress and future perspective," Diabetes \& Metabolic Syndrome, vol. 9, no. 4, pp. 343-358, 2015.

[5] S. S. Schwartz, S. Epstein, B. E. Corkey et al., "A unified pathophysiological construct of diabetes and its complications," Trends in Endocrinology \& Metabolism, vol. 28, no. 9, pp. 645-655, 2017.

[6] D. J. Betteridge, "What is oxidative stress?" Metabolism, vol. 49, no. 2, Supplement 1, pp. 3-8, 2000.

[7] I. Dalle-Donne, R. Rossi, R. Colombo, D. Giustarini, and A. Milzani, "Biomarkers of oxidative damage in human disease," Clinical Chemistry, vol. 52, no. 4, pp. 601-623, 2006.

[8] W. Dröge, "Free radicals in the physiological control of cell function," Physiological Reviews, vol. 82, no. 1, pp. 47-95, 2002.

[9] L. Covarrubias, D. Hernández-García, D. Schnabel, E. SalasVidal, and S. Castro-Obregón, "Function of reactive oxygen species during animal development: passive or active?" Developmental Biology, vol. 320, no. 1, pp. 1-11, 2008.

[10] J. Johansen, A. K. Harris, D. J. Rychly, and A. Ergul, "Oxidative stress and the use of antioxidants in diabetes: linking basic science to clinical practice," Cardiovascular Diabetology, vol. 4, no. 1, pp. 5-11, 2005.

[11] S. Dimmeler and A. M. Zeiher, "Reactive oxygen species and vascular cell apoptosis in response to angiotensin II and proatherosclerotic factors," Regulatory Peptides, vol. 90, no. 1-3, pp. 19-25, 2000.

[12] L. Van Heerebeek, C. Meischl, W. Stooker, C. J. L. M. Meijer, H. W. M. Niessen, and D. Roos, "NADPH oxidase(s): new source(s) of reactive oxygen species in the vascular system?," Journal of Clinical Pathology, vol. 55, no. 8, pp. 561-568, 2002.

[13] E. Panieri and M. M. Santoro, "ROS signaling and redox biology in endothelial cells," Cellular and Molecular Life Sciences, vol. 72, no. 17, pp. 3281-3303, 2015.

[14] M. Kuwabara, Z. Zhi-Yi, and G. Yoshii, "ESR of spintrapped radicals in aqueous solutions of pyrimidine nucleosides and nucleotides. Reactions of the hydroxyl radical," International Journal of Radiation Biology and Related Studies in Physics, Chemistry and Medicine, vol. 41, no. 3, pp. 241-259, 1982.

[15] D. Pastori, R. Carnevale, and P. Pignatelli, "Is there a clinical role for oxidative stress biomarkers in atherosclerotic diseases?," Internal and Emergency Medicine, vol. 9, no. 2, pp. 123-131, 2014. 
[16] R. Hille and V. Massey, "Studies on the oxidative halfreaction of xanthine oxidase," Journal of Biological Chemistry, vol. 256, no. 17, pp. 9090-9095, 1981.

[17] A. Sturza, O. M. Duicu, A. Vaduva et al., "Monoamine oxidases are novel sources of cardiovascular oxidative stress in experimental diabetes," Canadian Journal of Physiology and Pharmacology, vol. 93, no. 7, pp. 555-561, 2015.

[18] S. Karbach, P. Wenzel, A. Waisman, T. Munzel, and A. Daiber, "eNOS uncoupling in cardiovascular diseasesthe role of oxidative stress and inflammation," Current Pharmaceutical Design, vol. 20, no. 22, pp. 3579-3594, 2014.

[19] A. S. Al-Abrash, F. A. Al-Quobaili, and G. N. Al-Akhras, "Catalase evaluation in different human diseases associated with oxidative stress," Saudi Medical Journal, vol. 21, no. 9, pp. 826-830, 2000.

[20] O. Baud, A. E. Greene, J. Li, H. Wang, J. J. Volpe, and P. A. Rosenberg, "Glutathione peroxidase-catalase cooperativity is required for resistance to hydrogen peroxide by mature rat oligodendrocytes," Journal of Neuroscience, vol. 24, no. 7, pp. 1531-1540, 2004.

[21] M. Navab, S. Hama-Levy, B. J. Van Lenten et al., "Mildly oxidized LDL induces an increased apolipoprotein J/paraoxonase ratio," Journal of Clinical Investigation, vol. 99, no. 8, pp. 2005-2019, 1997.

[22] M. Xue, H. Momiji, N. Rabbani et al., "Frequency modulated translocational oscillations of Nrf2 mediate the antioxidant response element cytoprotective transcriptional response," Antioxidants \& Redox Signaling, vol. 23, no. 7, pp. 613-629, 2015.

[23] L. Rochette, Y. Cottin, M. Zeller, and C. Vergely, "Carbon monoxide: mechanisms of action and potential clinical implications," Pharmacology \& Therapeutics, vol. 137, no. 2, pp. 133-152, 2013.

[24] G. Negi, V. Nakkina, P. Kamble, and S. S. Sharma, "Heme oxygenase-1, a novel target for the treatment of diabetic complications: focus on diabetic peripheral neuropathy," Pharmacological Research, vol. 102, pp. 158-167, 2015.

[25] S. Lenzen, J. Drinkgern, and M. Tiedge, "Low antioxidant enzyme gene expression in pancreatic islets compared with various other mouse tissues," Free Radical Biology and Medicine, vol. 20, no. 3, pp. 463-466, 1996.

[26] J. L. Evans, I. D. Goldfine, B. A. Maddux, and G. M. Grodsky, "Are oxidative stress-activated signaling pathways mediators of insulin resistance and beta-cell dysfunction?," Diabetes, vol. 52, no. 1, pp. 1-8, 2003.

[27] M. Brownlee, "Biochemistry and molecular cell biology of diabetic complications," Nature, vol. 414, no. 6865, pp. 813820, 2001.

[28] R. Kaur, M. Kaur, and J. Singh, "Endothelial dysfunction and platelet hyperactivity in type 2 diabetes mellitus: molecular insights and therapeutic strategies," Cardiovascular Diabetology, vol. 17, no. 1, p. 121, 2018.

[29] J. S. Teodoro, S. Nunes, A. P. Rolo, F. Reis, and C. M. Palmeira, "Therapeutic options targeting oxidative stress, mitochondrial dysfunction and inflammation to hinder the progression of vascular complications of diabetes," Frontiers in Physiology, vol. 9, pp. 1-18, 2019.

[30] H. Vlassara, "Recent progress in advanced glycation end products and diabetic complications," Diabetes, vol. 46, Supplement_2, pp. S19-S25, 1997.
[31] A. Guerin-Dubourg, A. Catan, E. Bourdon, and P. Rondeau, "Structural modifications of human albumin in diabetes," Diabetes and Metabolism, vol. 38, no. 2, pp. 171-178, 2012.

[32] J. Patche, D. Girard, A. Catan et al., "Diabetes-induced hepatic oxidative stress: a new pathogenic role for glycated albumin," Free Radical Biology and Medicine, vol. 102, pp. 133-148, 2017.

[33] A. Faria and S. J. Persaud, "Cardiac oxidative stress in diabetes: mechanisms and therapeutic potential," Pharmacology \& Therapeutics, vol. 172, pp. 50-62, 2017.

[34] N. Tanji, G. S. Markowitz, C. Fu et al., "Expression of advanced glycation end products and their cellular receptor RAGE in diabetic nephropathy and nondiabetic renal disease," Journal of the American Society of Nephrology, vol. 11, no. 9, pp. 1656-1666, 2000.

[35] Z. Hegab, S. Gibbons, L. Neyses, and M. A. Mamas, "Role of advanced glycation end products in cardiovascular disease," World Journal of Cardiology, vol. 4, no. 4, pp. 90-102, 2012.

[36] G. Davì, A. Falco, and C. Patrono, "Lipid peroxidation in diabetes mellitus," Antioxidants \& Redox Signaling, vol. 7, no. 12, pp. 256-268, 2005.

[37] Z. J. Guo, H. X. Niu, F. F. Hou et al., "Advanced oxidation protein products activate vascular endothelial cells via a RAGE-mediated signaling pathway," Antioxidants \& Redox Signaling, vol. 10, no. 10, pp. 1699-1712, 2008.

[38] S. X. Liu, F. F. Hou, Z. J. Guo et al., "Advanced oxidation protein products accelerate atherosclerosis through promoting oxidative stress and inflammation," Arteriosclerosis, Thrombosis, and Vascular Biology, vol. 26, no. 5, pp. 1156-1162, 2006.

[39] W. Martinet, M. W. M. Knaapen, G. R. Y. De Meyer, A. G. Herman, and M. M. Kockx, "Elevated levels of oxidative DNA damage and DNA repair enzymes in human atherosclerotic plaques," Circulation, vol. 106, no. 8, pp. 927-932, 2002.

[40] M. Lodovici, E. Bigagli, F. Tarantini, C. Di Serio, and L. Raimondi, "Losartan reduces oxidative damage to renal DNA and conserves plasma antioxidant capacity in diabetic rats," Experimental Biology and Medicine, vol. 240, no. 11, pp. 1500-1504, 2015.

[41] J. D. Erusalimsky and C. Skene, "Mechanisms of endothelial senescence," Experimental Physiology, vol. 94, no. 3, pp. 299-304, 2009.

[42] H. E. Poulsen, E. Specht, K. Broedbaek et al., "RNA modifications by oxidation: a novel disease mechanism?," Free Radical Biology and Medicine, vol. 52, no. 8, pp. 1353-1361, 2012.

[43] W. X. Wang, S. B. Luo, P. Jiang et al., "Increased oxidative damage of RNA in early-stage nephropathy in $\mathrm{db} / \mathrm{db}$ mice," Oxidative Medicine and Cellular Longevity, vol. 2017, Article ID 2353729, 12 pages, 2017.

[44] J. P. Szaflik, P. Rusin, A. Zaleska-Zmijewska, M. Kowalski, I. Majsterek, and J. Szaflik, "Reactive oxygen species promote localized DNA damage in glaucoma-iris tissues of elderly patients vulnerable to diabetic injury," Mutation Research, vol. 697, no. 1-2, pp. 19-23, 2010.

[45] R. Blakytny and J. J. Harding, "Glycation (non-enzymic glycosylation) inactivates glutathione reductase," Biochemical Journal, vol. 288, no. 1, pp. 303-307, 1992.

[46] M. Kanwar, P. S. Chan, T. S. Kern, and R. A. Kowluru, "Oxidative damage in the retinal mitochondria of diabetic mice: possible protection by superoxide dismutase," Investigative 
Opthalmology \& Visual Science, vol. 48, no. 8, pp. 3805-3811, 2007.

[47] T. Nishikawa, D. Edelstein, X. L. Du et al., "Normalizing mitochondrial superoxide production blocks three pathways of hyperglycaemic damage," Nature, vol. 404, no. 6779, pp. 787-790, 2000.

[48] H. T. Chung, H. O. Pae, and Y. N. Cha, "Role of heme oxygenase-1 in vascular disease," Current Pharmaceutical Design, vol. 14, no. 5, pp. 422-428, 2008.

[49] J. A. Araujo, M. Zhang, and F. Yin, "Heme oxygenase-1, oxidation, inflammation, and atherosclerosis," Frontiers in Pharmacology, vol. 3, no. 119, pp. 1-17, 2012.

[50] B. Mackness, R. Quarck, W. Verreth, M. Mackness, and P. Holvoet, "Human Paraoxonase-1 Overexpression Inhibits Atherosclerosis in a Mouse Model of Metabolic Syndrome," Arteriosclerosis, Thrombosis, and Vascular Biology, vol. 26, no. 7, pp. 1545-1550, 2006.

[51] A. A. Elmarakby, J. Faulkner, B. Baban, and J. C. Sullivan, "Induction of hemeoxygenase-1 reduces renal oxidative stress and inflammation in diabetic spontaneously hypertensive rats," International Journal of Hypertension, vol. 2012, Article ID 957235, 11 pages, 2012.

[52] S. C. Lee, S. H. Han, J. J. Li et al., "Induction of heme oxygenase-1 protects against podocyte apoptosis under diabetic conditions," Kidney International, vol. 76, no. 8, pp. 838-848, 2009.

[53] M. Mastorikou, B. Mackness, Y. Liu, and M. Mackness, "Glycation of paraoxonase-1 inhibits its activity and impairs the ability of high-density lipoprotein to metabolize membrane lipid hydroperoxides," Diabetic Medicine, vol. 25, no. 9, pp. 1049-1055, 2008.

[54] S. H. Fatani, A. T. Babakr, E. M. NourEldin, and A. A. Almarzouki, "Lipid peroxidation is associated with poor control of type-2 diabetes mellitus," Diabetes \& Metabolic Syndrome, vol. 10, no. 2, Supplement 1, pp. S64-S67, 2016.

[55] I. Marrocco, F. Altieri, and I. Peluso, "Measurement and clinical significance of biomarkers of oxidative stress in humans," Oxidative Medicine and Cellular Longevity, vol. 2017, Article ID 6501046, 32 pages, 2017.

[56] D. A. Slatter, C. H. Bolton, and A. J. Bailey, "The importance of lipid-derived malondialdehyde in diabetes mellitus," Diabetologia, vol. 43, no. 5, pp. 550-557, 2000.

[57] M. Kant, M. Akış, M. Çalan et al., "Elevated urinary levels of 8 -oxo- $2^{\prime}$-deoxyguanosine, ( $\left.5^{\prime} \mathrm{R}\right)$ - and $\left(5^{\prime} \mathrm{S}\right)-8,5^{\prime}$-cyclo- $2^{\prime}$ -deoxyadenosines, and 8-iso-prostaglandin $\mathrm{F} 2 \alpha$ as potential biomarkers of oxidative stress in patients with prediabetes," DNA Repair, vol. 48, pp. 1-7, 2016.

[58] M. Huang, Y. Que, and X. Shen, "Correlation of the plasma levels of soluble RAGE and endogenous secretory RAGE with oxidative stress in pre-diabetic patients," Journal of Diabetes and its Complications, vol. 29, no. 3, pp. 422-426, 2015.

[59] L. Maschirow, K. Khalaf, H. A. Al-Aubaidy, and H. F. Jelinek, "Inflammation, coagulation, endothelial dysfunction and oxidative stress in prediabetes-biomarkers as a possible tool for early disease detection for rural screening," Clinical Biochemistry, vol. 48, no. 9, pp. 581-585, 2015.

[60] S. de M. Bandeira, G. da S. Guedes, L. J. da Fonseca et al., "Characterization of blood oxidative stress in type 2 diabetes mellitus patients: increase in lipid peroxidation and SOD activity," Oxidative Medicine and Cellular Longevity, vol. 2012, Article ID 819310, 13 pages, 2012.
[61] A. Strom, K. Kaul, J. Brüggemann et al., "Lower serum extracellular superoxide dismutase levels are associated with polyneuropathy in recent-onset diabetes," Experimental \& Molecular Medicine, vol. 49, no. 11, p. e394, 2017.

[62] K. A. Adeshara, A. G. Diwan, T. R. Jagtap, K. Advani, A. Siddiqui, and R. S. Tupe, "Relationship between plasma glycation with membrane modification, oxidative stress and expression of glucose trasporter-1 in type 2 diabetes patients with vascular complications," Journal of Diabetes and its Complications, vol. 31, no. 2, pp. 439-448, 2017.

[63] E. Bigagli, L. Raimondi, E. Mannucci et al., "Lipid and protein oxidation products, antioxidant status and vascular complications in poorly controlled type 2 diabetes," The British Journal of Diabetes \& Vascular Disease, vol. 12, no. 1, pp. 33-39, 2012.

[64] D. Chawla, S. Bansal, B. D. Banerjee, S. V. Madhu, O. P. Kalra, and A. K. Tripathi, "Role of advanced glycation end product (AGE)-induced receptor (RAGE) expression in diabetic vascular complications," Microvascular Research, vol. 95, pp. 1-6, 2014.

[65] C. T. De Souza, E. P. Araújo, L. F. Stoppiglia et al., "Inhibition of UCP2 expression reverses diet-induced diabetes mellitus by effects on both insulin secretion and action," The FASEB Journal, vol. 21, no. 4, pp. 1153-1163, 2007.

[66] H. K. Morsi, M. M. Ismail, H. A. H. Gaber, and A. A. Elbasmy, "Macrophage migration inhibitory factor and malondialdehyde as potential predictors of vascular risk complications in type 2 diabetes mellitus: cross-sectional case control study in Saudi Arabia," Mediators of Inflammation, vol. 2016, Article ID 5797930, 8 pages, 2016.

[67] A. Jiménez-Osorio, A. Picazo, S. González-Reyes, D. BarreraOviedo, M. Rodríguez-Arellano, and J. Pedraza-Chaverri, "Nrf2 and redox status in prediabetic and diabetic patients," International Journal of Molecular Sciences, vol. 15, no. 11, pp. 20290-20305, 2014.

[68] M. Lodovici, E. Bigagli, C. Luceri, E. Mannucci, C. M. Rotella, and L. Raimondi, "Gender-related drug effect on several markers of oxidation stress in diabetes patients with and without complications," European Journal of Pharmacology, vol. 766, pp. 86-90, 2015.

[69] A. Grindel, B. Guggenberger, L. Eichberger et al., "Oxidative stress, DNA damage and DNA repair in female patients with diabetes mellitus type 2," PLoS One, vol. 11, no. 9, p. e0162082, 2016.

[70] B. Djindjic, T. Kostic, Z. Radovanovic et al., "The contributions of fasting and postprandial blood glucose increments to oxidative stress and inflammation in dyslipidemic type 2 diabetic patients with stable ischemic heart disease," International Journal of Cardiology, vol. 227, pp. 611-616, 2017.

[71] S. Gupta, J. K. Gambhir, O. Kalra et al., “Association of biomarkers of inflammation and oxidative stress with the risk of chronic kidney disease in type 2 diabetes mellitus in North Indian population," J Diabetes Complications, vol. 27, no. 6, pp. 548-552, 2013.

[72] C. I. Bondor, A. R. Potra, D. Moldovan et al., "Relationship of adiponectin to markers of oxidative stress in type 2 diabetic patients: influence of incipient diabetes-associated kidney disease," International Urology and Nephrology, vol. 47, no. 7, pp. 1173-1180, 2015.

[73] S. T. Chou and S. T. Tseng, "Oxidative stress markers in type 2 diabetes patients with diabetic nephropathy," Clinical and Experimental Nephrology, vol. 21, no. 2, pp. 283-292, 2017. 
[74] S. Y. Goh and M. E. Cooper, "Clinical review: the role of advanced glycation end products in progression and complications of diabetes," The Journal of Clinical Endocrinology \& Metabolism, vol. 93, no. 4, pp. 1143-1152, 2008.

[75] N. Ahmed, "Advanced glycation endproducts-role in pathology of diabetic complications," Diabetes Research and Clinical Practice, vol. 67, no. 1, pp. 3-21, 2005.

[76] V. Jakuš, E. Sándorová, J. Kalninová, and B. Krahulec, “Monitoring of glycation, oxidative stress and inflammation in relation to the occurrence of vascular complications in patients with type 2 diabetes mellitus," Physiological Research, vol. 63, no. 3, pp. 297-309, 2014.

[77] A. Guerin-Dubourg, M. Cournot, C. Planesse et al., "Association between fluorescent advanced glycation end-products and vascular complications in type 2 diabetic patients," BioMed Research International, vol. 2017, Article ID 7989180, 10 pages, 2017.

[78] A. Saremi, S. Howell, D. C. Schwenke et al., "Advanced glycation end products, oxidation products, and the extent of atherosclerosis during the VA diabetes trial and follow-up study," Diabetes Care, vol. 40, no. 4, pp. 591-598, 2017.

[79] J. Koska, A. Saremi, S. Howell et al., "Advanced glycation end products, oxidation products, and incident cardiovascular events in patients with type 2 diabetes," Diabetes Care, vol. 41, no. 3, pp. 570-576, 2018.

[80] M. Cournot, E. Burillo, P. J. Saulnier et al., "Circulating concentrations of redox biomarkers do not improve the prediction of adverse cardiovascular events in patients with type 2 diabetes mellitus," Journal of the American Heart Association, vol. 7, no. 5, pp. 1-14, 2018.

[81] M. Nativel, F. Schneider, P. J. Saulnier et al., "Prognostic values of inflammatory and redox status biomarkers on the risk of major lower-extremity artery disease in individuals with type 2 diabetes," Diabetes Care, vol. 41, no. 10, pp. 2162-2169, 2018.

[82] B. Gryszczyńska, D. Formanowicz, M. Budzyń et al., "Advanced oxidation protein products and carbonylated proteins as biomarkers of oxidative stress in selected atherosclerosis-mediated diseases," BioMed Research International, vol. 2017, Article ID 4975264, 9 pages, 2017.

[83] D. Weber, M. J. Davies, and T. Grune, "Determination of protein carbonyls in plasma, cell extracts, tissue homogenates, isolated proteins: focus on sample preparation and derivatization conditions," Redox Biology, vol. 5, pp. 367380, 2015.

[84] K. B. Pandey, N. Mishra, and S. I. Rizvi, "Protein oxidation biomarkers in plasma of type 2 diabetic patients," Clinical Biochemistry, vol. 43, no. 4-5, pp. 508-511, 2010.

[85] A. Piwowar, M. Knapik-Kordecka, and M. Warwas, "Comparison of the usefulness of plasma levels of oxidatively modified forms of albumin in estimating kidney dysfunction in diabetic patients," Clinical and Investigative Medicine, vol. 33, no. 2, p. E109, 2010.

[86] M. Liang, J. Wang, C. Xie et al., "Increased plasma advanced oxidation protein products is an early marker of endothelial dysfunction in type 2 diabetes patients without albuminuria," Journal of Diabetes, vol. 6, no. 5, pp. 417-426, 2014.

[87] P. I. Margetis, M. H. Antonelou, I. K. Petropoulos, L. H. Margaritis, and I. S. Papassideri, "Increased protein carbonylation of red blood cell membrane in diabetic retinopathy," Experimental and Molecular Pathology, vol. 87, no. 1, pp. 76-82, 2009.
[88] F. Casoinic, D. Sampelean, A. D. Buzoianu, N. Hancu, and D. Baston, "Serum levels of oxidative stress markers in patients with type 2 diabetes mellitus and non-alcoholic steatohepatitis," Romanian Journal of Internal Medicine, vol. 54, no. 4, pp. 228-236, 2016.

[89] M. Lodovici, S. Caldini, C. Luceri, F. Bambi, V. Boddi, and P. Dolara, "Active and passive smoking and lifestyle determinants of 8-oxo-7,8-dihydro- $2^{\prime}$-deoxyguanosine levels in human leukocyte DNA," Cancer Epidemiology Biomarkers \& Prevention, vol. 14, no. 12, pp. 2975-2977, 2005.

[90] M. Serdar, E. Sertoglu, M. Uyanik et al., "Comparison of 8hydroxy-2' -deoxyguanosine (8-OHdG) levels using mass spectrometer and urine albumin creatinine ratio as a predictor of development of diabetic nephropathy," Free Radical Research, vol. 46, no. 10, pp. 1291-1295, 2012.

[91] X. Liu, W. Gan, Y. Zou et al., "Elevated levels of urinary markers of oxidative DNA and RNA damage in type 2 diabetes with complications," Oxidative Medicine and Cellular Longevity, vol. 2016, Article ID 4323198, 7 pages, 2016.

[92] H. F. Jelinek, A. Stranieri, A. Yatsko, and S. Venkatraman, "Data analytics identify glycated haemoglobin co-markers for type 2 diabetes mellitus diagnosis," Computers in Biology and Medicine, vol. 75, pp. 90-97, 2016.

[93] E. Tatsch, J. A. De Carvalho, B. S. Hausen et al., "Oxidative DNA damage is associated with inflammatory response, insulin resistance and microvascular complications in type 2 diabetes," Mutation Research, vol. 782, pp. 17-22, 2015.

[94] K. Broedbaek, V. Siersma, T. Henriksen et al., "Urinary markers of nucleic acid oxidation and long-term mortality of newly diagnosed type 2 diabetic patients," Diabetes Care, vol. 34, no. 12, pp. 2594-2596, 2011.

[95] M. C. Thomas, M. Woodward, Q. Li et al., "Relationship between plasma 8-OH-deoxyguanosine and cardiovascular disease and survival in type 2 diabetes mellitus: results from the ADVANCE trial," Journal of the American Heart Association, vol. 7, no. 13, pp. 1-17, 2018.

[96] L. K. Kjær, V. Cejvanovic, T. Henriksen et al., "Cardiovascular and all-cause mortality risk associated with urinary excretion of 8-oxoGuo, a biomarker for RNA oxidation, in patients with type 2 diabetes: a prospective cohort study," Diabetes Care, vol. 40, no. 12, pp. 1771-1778, 2017.

[97] K. Broedbaek, R. Køster-Rasmussen, V. Siersma, F. Persson, H. E. Poulsen, and N. de Fine Olivarius, "Urinary albumin and 8-oxo-7,8-dihydroguanosine as markers of mortality and cardiovascular disease during 19 years after diagnosis of type 2 diabetes - a comparative study of two markers to identify high risk patients," Redox Biology, vol. 13, pp. 363-369, 2017.

[98] K. Gawlik, J. W. Naskalski, D. Fedak et al., "Markers of antioxidant defense in patients with type 2 diabetes," Oxidative Medicine and Cellular Longevity, vol. 2016, Article ID 2352361, 6 pages, 2016.

[99] A. Picu, L. Petcu, S. Ştefan et al., "Markers of oxidative stress and antioxidant defense in Romanian patients with type 2 diabetes mellitus and obesity," Molecules, vol. 22, no. 5, p. 714, 2017.

[100] M. Lodovici, L. Giovannelli, V. Pitozzi, E. Bigagli, G. Bardini, and C. M. Rotella, "Oxidative DNA damage and plasma antioxidant capacity in type 2 diabetic patients with good and poor glycaemic control," Mutation Research, vol. 638, no. 12, pp. 98-102, 2008. 
[101] R. González de Vega, M. L. Fernández-Sánchez, J. C. Fernández, F. V. Álvarez Menéndez, and A. Sanz-Medel, "Selenium levels and glutathione peroxidase activity in the plasma of patients with type II diabetes mellitus," Journal of Trace Elements in Medicine and Biology, vol. 37, pp. 44-49, 2016.

[102] M. Wamique, W. Ali, D. H. Reddy, P. Vishwakarma, and M. Waseem, "A case control study on HDL associated PON1 enzyme level in Northern Indian type 2 diabetes mellitus patients," Diabetes \& Metabolic Syndrome, vol. 12, no. 6, pp. 843-847, 2018.

[103] R. Shakeri, S. Khajeniazi, and A. Marjani, "Association between promoter polymorphism $(-108 \mathrm{C}>\mathrm{T})$ of paraoxonase1 gene and it(')s paraoxonase activity in patients with type2 diabetes in northern Iran," Clinica Chimica Acta, vol. 474, pp. 34-37, 2017.

[104] A. Passaro, G. B. Vigna, A. Romani et al., "Distribution of paraoxonase-1 (PON-1) and lipoprotein phospholipase A2 (Lp-PLA2) across lipoprotein subclasses in subjects with type 2 diabetes," Oxidative Medicine and Cellular Longevity, vol. 2018, Article ID 1752940, 10 pages, 2018.

[105] Y. U. Budak, M. Akdogan, and K. Huysal, "Relationship of PON1 activity and hsCRP concentration with disease status in patients with type 2 diabetes mellitus with and without retinopathy," International Journal of Diabetes in Developing Countries, vol. 33, no. 1, pp. 40-45, 2013.

[106] S. Bansal, D. Chawla, B. D. Banerjee, S. V. Madhu, and A. K. Tripathi, "Association of RAGE gene polymorphism with circulating AGEs level and paraoxonase activity in relation to macro-vascular complications in Indian type 2 diabetes mellitus patients," Gene, vol. 526, no. 2, pp. 325-330, 2013.

[107] Y. Ikeda, M. Inoue, T. Suehiro, K. Arii, Y. Kumon, and K. Hashimoto, "Low human paraoxonase predicts cardiovascular events in Japanese patients with type 2 diabetes," Acta Diabetologica, vol. 46, no. 3, pp. 239-242, 2009.

[108] J. A. Crow, E. C. Meek, R. W. Wills, and J. E. Chambers, “A case-control study: the association of serum paraoxonase 1 activity and concentration with the development of type 2 diabetes mellitus," Diabetes/Metabolism Research and Reviews, vol. 34, no. 3, p. e2967, 2018.

[109] S. K. Kunutsor, L. M. Kieneker, S. J. L. Bakker, R. W. James, and R. P. F. Dullaart, "Incident type 2 diabetes is associated with HDL, but not with its anti-oxidant constituent - paraoxonase-1: the prospective cohort PREVEND study," Metabolism, vol. 73, pp. 43-51, 2017.

[110] W. Bao, F. Song, X. Li et al., "Plasma heme oxygenase-1 concentration is elevated in individuals with type 2 diabetes mellitus," PLoS One, vol. 5, no. 8, p. e12371, 2010.

[111] Z. Li, Y. Xu, X. Liu, Y. Nie, and Z. Zhao, "Urinary heme oxygenase-1 as a potential biomarker for early diabetic nephropathy," Nephrology, vol. 22, no. 1, pp. 58-64, 2017.

[112] S. Mehrotra, K. L. E. Ling, Y. Bekele, E. Gerbino, and K. A. Earle, "Lipid hydroperoxide and markers of renal disease susceptibility in African-Caribbean and Caucasian patients with type 2 diabetes mellitus," Diabetic Medicine, vol. 18, no. 2, pp. 109-115, 2001.

[113] R. H. Asmah, G. Yeboah, H. Asare-Anane et al., "Relationship between oxidative stress and haematological indices in patients with diabetes in the Ghanaian population," Clinical Diabetes and Endocrinology, vol. 1, no. 1, pp. 1-5, 2015.

[114] Q. Chen, Q. Wang, J. Zhu, Q. Xiao, and L. Zhang, "Reactive oxygen species: key regulators in vascular health and diseases," British Journal of Pharmacology, vol. 175, no. 8, pp. 1279-1292, 2018.

[115] D. Wu, C. Wu, and Y. Zhong, "The association between paraoxonase 1 activity and the susceptibilities of diabetes mellitus, diabetic macroangiopathy and diabetic microangiopathy," Journal of Cellular and Molecular Medicine, vol. 22, no. 9, pp. 4283-4291, 2018.

[116] M. Seddon, Y. H. Looi, and A. M. Shah, "Oxidative stress and redox signalling in cardiac hypertrophy and heart failure," Heart, vol. 93, no. 8, pp. 903-907, 2007.

[117] M. Y. Wu, G. T. Yiang, T. T. Lai, and C. J. Li, "The oxidative stress and mitochondrial dysfunction during the pathogenesis of diabetic retinopathy," Oxidative Medicine and Cellular Longevity, vol. 2018, Article ID 3420187, 12 pages, 2018.

[118] J. C. Jha, C. Banal, B. S. M. Chow, M. E. Cooper, and K. Jandeleit-Dahm, "Diabetes and kidney disease: role of oxidative stress," Antioxidants \& Redox Signaling, vol. 25, no. 12, pp. 657-684, 2016.

[119] R. Kulkarni, J. Acharya, S. Ghaskadbi, and P. Goel, "Oxidative stress as a covariate of recovery in diabetes therapy," Frontiers in Endocrinology, vol. 5, pp. 89-91, 2014. 


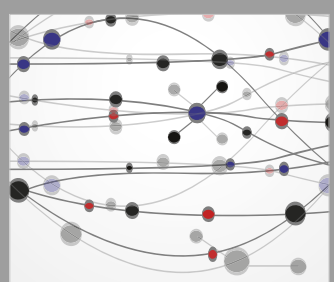

The Scientific World Journal
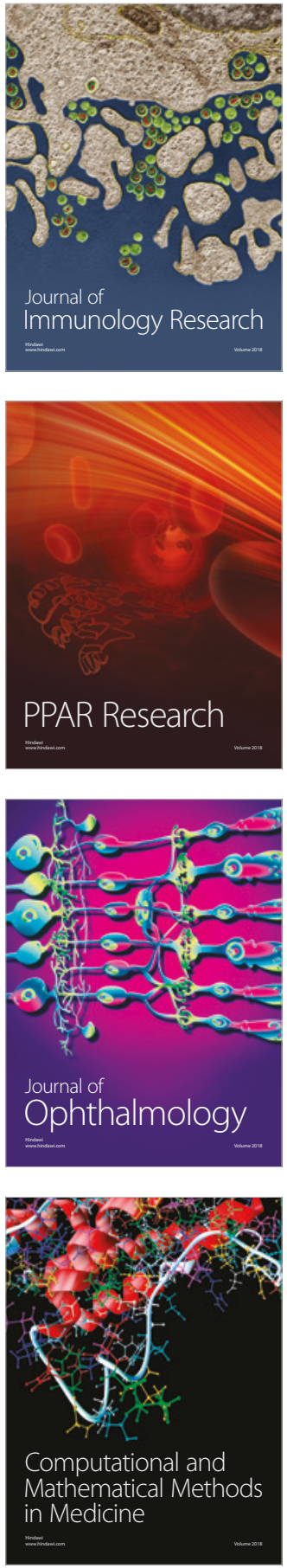

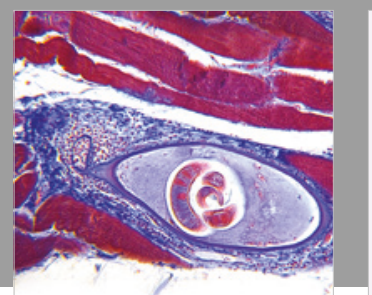

Gastroenterology Research and Practice

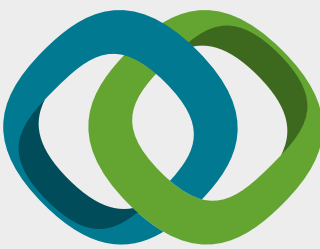

\section{Hindawi}

Submit your manuscripts at

www.hindawi.com
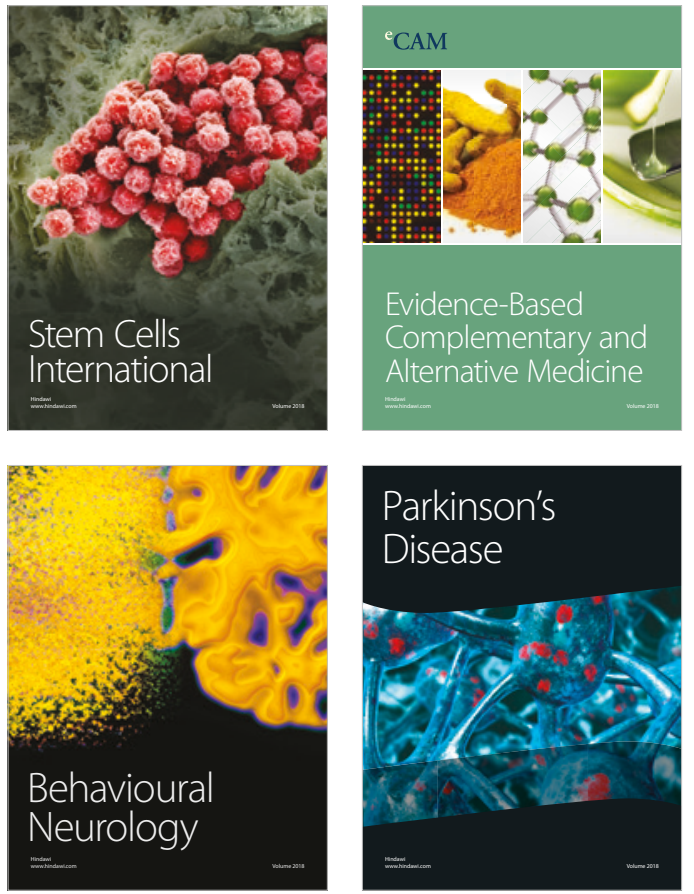

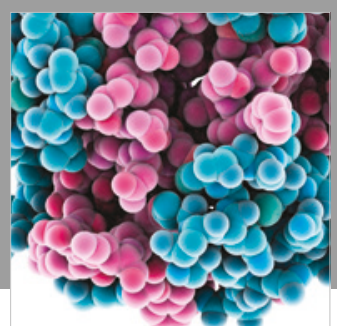

ournal of

Diabetes Research

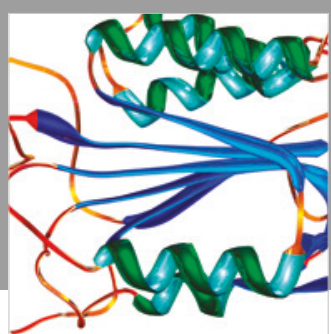

Disease Markers
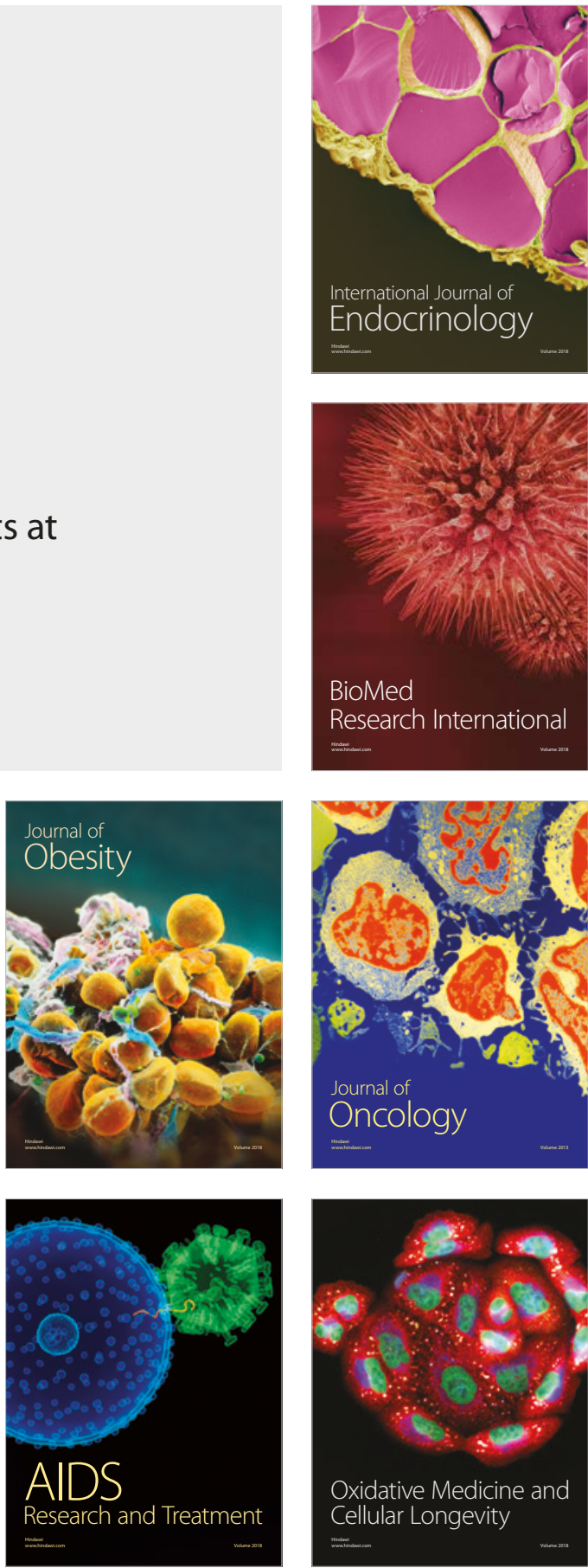